\title{
Nitrilases in nitrile biocatalysis: recent progress and forthcoming research
}

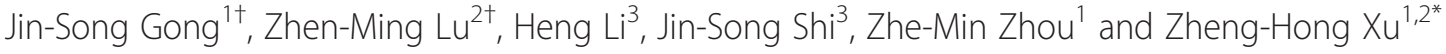

\begin{abstract}
Over the past decades, nitrilases have drawn considerable attention because of their application in nitrile degradation as prominent biocatalysts. Nitrilases are derived from bacteria, filamentous fungi, yeasts, and plants. In-depth investigations on their natural sources function mechanisms, enzyme structure, screening pathways, and biocatalytic properties have been conducted. Moreover, the immobilization, purification, gene cloning and modifications of nitrilase have been dwelt upon. Some nitrilases are used commercially as biofactories for carboxylic acids production, waste treatment, and surface modification. This critical review summarizes the current status of nitrilase research, and discusses a number of challenges and significant attempts in its further development. Nitrilase is a significant and promising biocatalyst for catalytic applications.
\end{abstract}

Keywords: Biocatalysis, Bioremediation, Carboxylic acid, Gene expression, Immobilization, Nitrilase, Nitrile, Purification, Strain screening, Surface modification

\section{Background}

\section{Green chemistry}

Chemistry, as one of the oldest disciplines, has achieved great advances over the past centuries, owing to the discoveries by scholars in industry and academia worldwide [1]. In addition, chemistry has outstanding contributions to the development of the global economy, and the progress of human civilization. However, along with the diminishing fossil fuel reserves, and the increasing environmental pollution, research gradually focused on the development of economical, energy-saving, and environmentally benign chemical processes [1,2]. The global needs for clean production technologies, renewable raw materials and energy, and the treatment of hazardous chemicals and wastes presented new research challenges to both chemistry and biotechnology [3]. Hence, "green chemistry", traced from the concepts of atom economy and $E$ factors $(E$ = wastes produced/product obtained), was introduced and became a strategic focus in both industrial and academic areas in the 1990s $[2,4,5]$.

\footnotetext{
* Correspondence: zhenghxu@jiangnan.edu.cn

${ }^{\dagger}$ Equal contributors

'The Key Laboratory of Industrial Biotechnology, Ministry of Education, Jiangnan University, Wuxi, People's Republic of China

${ }^{2}$ Laboratory of Pharmaceutical Engineering, School of Medicine and

Pharmaceutics, Jiangnan University, Wuxi 214122, People's Republic of China Full list of author information is available at the end of the article
}

\section{Solution for green chemistry}

Biocatalysis, the core of industrial biotechnology, is a solution to green chemistry because of its excellent catalytic efficiency and environmentally benign characteristics $[1,3,6]$. Its rapid development came from the recent advances in large-scale genome sequencing, directed evolution, protein expression, metabolic engineering, high throughput screening, and structural biology [7]. Biocatalysis has emerged as a promising tool for the catalytic processes using whole microbial cells, cell extracts, purified enzymes, immobilized cells, or immobilized enzymes as the catalysts for chemical synthesis [8,9]. Enzymatic transformations have been carried out for the production of a wide range of chemicals, including food ingredients, active pharmaceuticals, pharmaceutical and agrochemical intermediates, detergents, and other bulk chemicals $[5,8,10,11]$. Furthermore, instead of the conventional chemical synthesis, the biocatalytic routes are developed to meet the green chemistry requirements on cost-efficiency, waste reduction, energy consumption, and other synthesizing objectives (ideally, to synthesize target compounds with $100 \%$ yield and $100 \%$ selectivity) $[1,5,12]$.

\section{Nitrile biocatalysis}

Nitrile compounds, as nitrile biocatalysis reaction substrates, are widespread in the natural environment, and

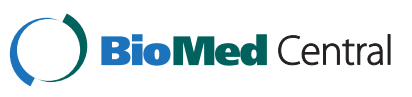


occur as cyanoglycosides, cyanolipids, ricinine, and phenylacetonitrile which were produced by plants [13]. In addition, nitriles are simple to synthesize using several pathways, such as the addition of a cyanide ion to alkyl halides, the Strecker reaction, the Sandmeyer reaction, and the reaction of aryl halides with copper cyanide [14]. Although most nitriles are highly toxic, mutagenic, and carcinogenic due to their cyano group, enzymatic hydrolysis of these compounds is a recognized method to avail a broad spectrum of useful amides, carboxylic acids, and so on [13,15]. Meanwhile, bioremediation with nitrile-converting enzymes is an efficient method for degrading highly toxic nitriles in environmental wastes and contaminants [16,17]. Nitrile catabolism comprises two distinct pathways [18]: (1) nitrilases (EC 3.5.5.1) directly convert nitriles to corresponding carboxylic acids and $\mathrm{NH}_{3}$; and (2) nitrile hydratases (NHases; EC 4.2.1.84) catalyze the formation of corresponding amides from nitriles, and amidases (EC 3.5.1.4) subsequently hydrolyze amides to carboxylic acids and $\mathrm{NH}_{3}$. This review focuses primarily on nitrilase research.

\section{Nitrilase}

In recent years, nitrilase-mediated biocatalysis has attracted substantial attention from scholars and entrepreneurs. Several studies on nitrilase application in chemical synthesis were carried out, since the first nitrilase was discovered in the early 1960s [19]. Over the past five decades, various nitrilase-producing organisms, including bacteria, filamentous fungi, yeasts, and plants were described $[13,20-22]$, and some of these microbial cell factories were utilized for the commercial production of carboxylic acids in industrial scale. The success of nicotinic acid (Lonza, China) and (R)-(-)-mandelic acid (Mitsubishi Rayon, Japan; BASF, Germany) industrial production using nitrilase proved the great economic potential of nitrilase [9,23-25]. Intensive research on nitrilase-mediated biocatalysis has occurred in the past decades, as shown by the increasing publications on enzymatic nitrile hydrolysis catalyzed by nitrilase (Figure 1). The present study summarizes the current scientific knowledge on nitrilase and thus lays the foundation for prospective industrial nitrilase applications. This review will concentrate on nitrilase occurrence, catalytic reaction mechanism, reaction properties, enzyme purification, immobilization, nitrilase gene cloning, molecular modification, and its industrial applications. Furthermore, this review will discuss the challenges faced by researchers and the future prospect in this field.

\section{Nitrilase sources}

Nitrilase activities exist extensively in nature, especially in bacteria, filamentous fungi and plants, although it is difficult to assess the actual distribution frequency of these organisms. On the other hand, the microbial

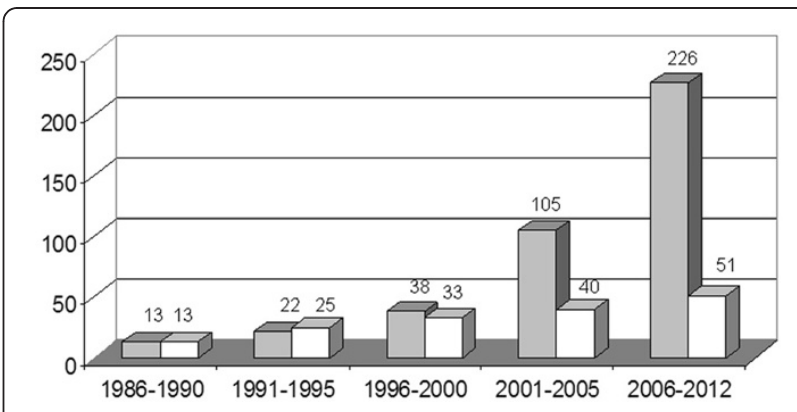

Figure 1 Number of publications on nitrilase research. Articles

(घ) were assessed according to Web of Science; patents ( $\square$ )

according to Espacenet search conducted at the end of July 2012.

nitrilase as a "green catalyst" for production of useful compounds with commercial value and other catalytic applications is easier to control from viewpoint of biotechnological application. Based on the substrate specificity of nitrilases from different sources, they were classified into three major categories, namely aromatic nitrilase, aliphatic nitrilase and arylacetonitrilase [26].

\section{Bacteria}

Since the 1960s, studies on nitrilase focused mainly on the bacteria that produce this enzyme. The first bacterial strain to hydrolyze the ricinine nitrile group was isolated from the soil, and was identified as belonging to the Pseudomonas genus based on primary morphological characteristics [27]. Ricinine nitrilase from this Pseudomonas strain was then purified, and characterized [28]. Henceforth, several bacteria from the genera of Rhodococcus, Nocardia, Acinetobacter, Alcaligenes, Pseudomonas, Corynebacterium, and so on, were reported to display nitrilase activity (Table 1); among which, several nitrilases were purified, characterized, immobilized, gene cloned, over-expressed in host strains, and applied in industrial processes. The success of nitrile-converting enzymes from $R$. rhodochrous J1, which were utilized in industrial production of amides and carboxylic acids substantially boosted the confidence of researchers and entrepreneurs in this area. Thus, during the last two decades, the number of reported bacteria with nitrilases rapidly increased yearly.

\section{Filamentous fungi}

In earlier studies, nitrilase activity was reported in several fungal strains from the genera of Fusarium, Gibberella, Aspergillus, and Penicillium, which can hydrolyze indole3-acetonitrile (IAN) into indole-3-acetic acid (IAA) [19]; however, little information is available on fungal nitrilase in the following decades. More precisely, only a F. solani was reported capable of degradation of the herbicides 3,5dibromo-4-hydroxybenzonitrile (bromoxynil) and 3,5diiodo-4-hydroxybenzonitrile (ioxynil) by $\mathrm{Hsu}$ and 
Table 1 The reported bacteria with nitrilase activity in previous literature

\begin{tabular}{|c|c|c|c|c|c|c|c|}
\hline Bacteria & $\begin{array}{l}\text { Formation } \\
\text { type }\end{array}$ & $\begin{array}{l}\text { Molecular } \\
\text { weight (kDa) }\end{array}$ & $\begin{array}{l}\text { Optimum } \mathrm{pH} / \\
\text { temperature }\left({ }^{\circ} \mathrm{C}\right)\end{array}$ & $\begin{array}{l}\text { Stability } \mathrm{pH} / \\
\text { temperature }\left({ }^{\circ} \mathrm{C}\right)\end{array}$ & Substrate specificity & $K \mathrm{~m}(\mathrm{M})$ & Reference \\
\hline Pseudomonas sp. & Inducible & - & - & $7.4-8.8 /-$ & $\begin{array}{l}\text { N-Methyl/ethyl-3-cyano-4- } \\
\text { methoxy-2-pyridone }\end{array}$ & $1.9 \times 10^{-5}$ & [27] \\
\hline Nocardia sp. NCIB 11216 & Inducible & 560 & $8 /-$ & - & Aromatic nitrile & - & [29] \\
\hline Brevibacterium strain R312 & Constitutive & - & $7 / 35$ & - / below 30 & - & $2.5 \times 10^{-2}$ & [30] \\
\hline Pseudomonas sp. 13 & Inducible & 1,000 & $9 / 55$ & 7-11 / below 60 & $\beta$-Cyano-L-alanine & $8.3 \times 10^{-2}$ & {$[31]$} \\
\hline Acinetobaeter sp. APN & Inducible & - & - & - & a-Aminonitriles & $3.4 \times 10^{-2}$ & {$[32]$} \\
\hline R. rhodochrous J1 & Inducible & 78 & $7.6 / 45$ & $-/ 20-50$ & Aliphatic, aromatic nitriles & - & {$[33,34]$} \\
\hline Comamonas testosteroni sp. & Inducible & - & - & - & Aliphatic nitriles & - & [35] \\
\hline A. faecalis JM3 & Inducible & 275 & $7.5 / 45$ & $7-8 / 20-50$ & Arylacetonitriles & $3.3 \times 10^{-4}$ & {$[36]$} \\
\hline Acinetobacter sp. AK226 & Inducible & 580 & $8 / 50$ & 5.8-8 / below 60 & $\begin{array}{l}\text { Aliphatic, heterocyclic } \\
\text { nitriles }\end{array}$ & $1.2 \times 10^{-2}$ & {$[37]$} \\
\hline A. faecalis ATCC 8750 & Inducible & 460 & $7.5 / 40-45$ & 6.5-8 / below 50 & Arylacetonitriles & $5.8 \times 10^{-3}$ & {$[38]$} \\
\hline R. rhodochrous PA-34 & Inducible & 45 & $7.5 / 35$ & - / below 35 & Aromatic, aliphatic nitriles & $4.5 \times 10^{-2}$ & [39] \\
\hline R. rhodochrous $\mathrm{K} 22$ & Inducible & 650 & $5.5 / 50$ & - / below 55 & Aliphatic nitriles & $1.9 \times 10^{-2}$ & {$[40]$} \\
\hline Klebsiella ozaenae & Constitutive & 37 & $9.2 / 35$ & - & Bromoxynil & $3.1 \times 10^{-4}$ & [41] \\
\hline Bacillus pallidus Dac521 & Inducible & 600 & $7.6 / 65$ & 6-9 / below 65 & Aromatic nitriles & $9.2 \times 10^{-4}$ & {$[42]$} \\
\hline R. rhodochrous NCIMB 11216 & Inducible & 45.8 & $8 / 30$ & - & Aromatic nitriles & $2.1 \times 10^{-2}$ & [43] \\
\hline P. fluorescens DSM 7155 & Inducible & 130 & $9 / 55$ & - & Arylacetonitriles & $8.7 \times 10^{-5}$ & [44] \\
\hline N. globerula NHB-2 & Inducible & - & - & - & $\begin{array}{l}\text { Aromatic, unsaturated } \\
\text { aliphatic nitriles }\end{array}$ & - & {$[45]$} \\
\hline P. putida & Inducible & 412 & $7 / 40$ & 6.5-8 / below 50 & Arylacetonitriles & $1.3 \times 10^{-2}$ & [46] \\
\hline Pyrococcus abyssi GE5 & Inducible & 60 & $7.4 / 80$ & $4.5-8.5 / 60-90$ & Aliphatic dinitriles & $9.5 \times 10^{-3}$ & {$[47]$} \\
\hline Acidovorax facilis $72 \mathrm{~W}$ & Inducible & 570 & $-/ 65$ & 5-10 / below 60 & Aliphatic dinitriles & $5.6 \times 10^{-2}$ & [48] \\
\hline Rhodococcus sp. NDB1165 & Inducible & - & $8 / 45$ & - / below 50 & $\begin{array}{l}\text { Aromatic and unsaturated } \\
\text { aliphatic nitriles }\end{array}$ & 0.1 & [49] \\
\hline $\begin{array}{l}\text { Bradyrhizobium japonicum } \\
\text { USDA110 }\end{array}$ & Inducible & 455 & - & - & $\begin{array}{l}\text { Mandelonitrile, } \\
\text { phenylacetonitrile }\end{array}$ & $2.6 \times 10^{-4}$ & {$[50]$} \\
\hline P. aeruginosa 10145 & Inducible & - & - & - & Aromatic nitriles & - & [51] \\
\hline Halomonas nitrilicus sp. nov. & Inducible & - & - & - & Arylaliphatic nitriles & - & {$[52]$} \\
\hline Bacillus subtilis ZJB-063 & Constitutive & - & - & - & Arylacetonitriles & - & [53] \\
\hline Alcaligenes sp. ECU0401 & Constitutive & 376 & $8 / 40$ & - / below 50 & $\begin{array}{l}\text { Aliphatic and aromatic } \\
\text { nitriles }\end{array}$ & $2.2 \times 10^{-2}$ & {$[54]$} \\
\hline P. fluorescens Pf-5 & - & 138 & $7 / 45$ & - / below 65 & Dinitriles & $1.8 \times 10^{-2}$ & {$[55]$} \\
\hline Streptomyces sp. MTCC 7546 & Inducible & - & - & - & Aliphatic nitriles & - & {$[56]$} \\
\hline $\begin{array}{l}\text { Arthrobacter nitroguajacolicus } \\
\text { ZJUTB06-99 }\end{array}$ & Inducible & - & $6.5 / 40$ & - / below 50 & $\begin{array}{l}\text { Aliphatic and aromatic } \\
\text { nitriles }\end{array}$ & $1.2 \times 10^{-2}$ & [57] \\
\hline R. erythropolis ZJB-0910 & Inducible & - & $7.5 / 30$ & - / below 30 & $\beta$-Hydroxy aliphatic nitrile & $1.0 \times 10^{-2}$ & {$[58]$} \\
\hline Geobacillus pallidus RAPc8 & Inducible & 600 & - & - & Aromatic nitriles & - & [59] \\
\hline A. faecalis ZJUTB10 & Inducible & - & $7.7-8.5 / 35$ & - / below 35 & - & - & {$[60]$} \\
\hline A. faecalis MTCC 10757 & Inducible & - & $8 / 35$ & - & $\begin{array}{l}\text { Aliphatic and aromatic } \\
\text { nitriles }\end{array}$ & - & [61] \\
\hline
\end{tabular}

Note: "-" indicates no data available.

Camper [62]. Thereafter, nitrilase from F. solani IMI 196840 [63], isolated from bromoxynil-treated soil and can grow with benzonitrile as its sole carbon and nitrogen source, was purified and characterized. The significance of nitrilase from F. solani IMI 196840 in the breakdown of herbicides in the environment was discussed. Since then, F. solani nitrilase was the only uniquely characterized fungal nitrilase for more than ten years until the appearance of F. oxysporum f. sp. melonis nitrilase in 1989 [64]. Later, a group from Czech Republic tackled nitrilase 
research, especially fungal nitrilases. Nitrilases from $A$. niger $\mathrm{K} 10$ and F. solani O1, used by this group, proved to be promising biocatalysts in nitrile transformation [65]. Both these new fungal nitrilases were purified, immobilized, and used to synthesize carboxylic acids [66-68]. Moreover, the aforementioned F. solani IMI 196840 nitrilase was further investigated [69]. Table 2 shows some reported filamentous fungi with nitrilase activity.

\section{Yeasts}

More than 60 nitrile-metabolizing yeasts, including the species of Candida, Pichia, Saccharomyces, Hanseniaspora, Debaryomyces, Geotrichum, Williopsis, Torulopsis, Exophiala, Kluyveromyces, Aureobasidium, Cryptococcus, and Rhodotorula, were isolated from cyanide treatment bioreactor, fermented foods, and the soil [71,72]. Nonetheless, most of these species contained the nitrile hydratase-amidase system, rather than the nitrilase system, for nitrile biocatalysis. Only few yeasts display nitrilase activities.

Fukuda et al. used an enrichment medium with $0.1 \%$ $\mathrm{D}, \mathrm{L}-\alpha$-hydroxy isovaleronitrile as the sole nitrogen source and obtained a T. candida GN405 strain that can effectively synthesize the optically active $\alpha$-hydroxyacids from D,L- $\alpha$-hydroxynitrile compounds, but failed to hydrolyze D,L- $\alpha$-aminonitriles [73]. Yeast nitrilasemediated biotransformation tends to occur under acidic conditions, out of consideration for the optimal $\mathrm{pH}$ for the growth of yeast strains (generally, 4.0-7.0). Thus, yeast nitrilase was suitable for the hydrolysis of hydroxynitriles and aminonitriles, which spontaneously decomposed under neutral conditions, but were more stable at acidic $\mathrm{pH}$. The nitrile-hydrolyzing yeast E. oligosperma R1, isolated in a selective medium of $\mathrm{pH} 4.0$, has significant stability and excellent catalytic efficiency for hydroxynitriles under acid conditions [21,74]. Rezende's study indicated that the nitrilase system of Cryptococcus sp. UFMG-Y28 could be induced in the presence of benzonitrile as the sole nitrogen source. Moreover, this strain was also found to produce nitrile hydratase (NHase) and amidase when grown on other nitriles as nitrogen source [75].

\section{Plants}

Plant nitrilase is an important enzyme in the nitrilase superfamily. Studies on plant nitrilases in its early days mainly focused on their potential in converting IAN into IAA, which is important in promoting elongation growth of plants. However, the function of nitrilases in plant auxin biosynthesis is still unclear [22]. The first plant nitrilase that hydrolyzed IAN to IAA in barley, was described by Thimann in 1964 [19]. Furthermore, several plant species were reported to contain various nitrile compounds [71], indicating that nitrilases widely exist in plants.

Nitrilase from Chinese cabbage seedlings was partial purified, and its significance for IAA synthesis was discussed [76]. The Brassica rapa nitrilases showed excellent activities for various aliphatic and aromatic nitriles, but poor for IAN [77]. Arylacetonitriles, such as 4-hydroxy and 4-methoxy phenylacetonitrile, were proven good substrates for Sinapis alba and S. arvensis nitrilase (the latter also showed NHase activity) [78]. Arabidopsis thaliana, a member of the Brassicaceae family, expressed four kinds of nitrilases (AtNIT1 to AtNIT4). AtNIT1 to AtNIT3, which can convert IAN into IAA, are very similar to each other, but less similar to AtNIT4 [79,80]. AtNIT4 has only $65 \%$ amino acids identical to that of the AtNIT1 to AtNIT3. The AtNIT4 gene is located on chromosome 5, whereas the AtNIT1 to AtNIT3 genes are clustered on chromosome 3 , and have more than $80 \%$ sequence identities [81]. Moreover, NIT4 gene is found to exist in all plants (from mosses on) [22,80]. NIT4 enzymes are mostly very specific for $\beta$-cyano-L-alanine, which is an intermediate product in the plant cyanide detoxification pathway $[79,82]$.

Recent studies on plant nitrilases demonstrated their cyanide detoxification function. Cyanide, which is highly toxic, is produced as by-product in biosynthesis of the plant hormone ethylene in all plants [83]. On the other hand, the other possible sources of cyanide in some plants was cyanogenic glycosides, which are plant defense compounds and can be degraded into an aldehyde, ketone or hydrogen cyanide by $\beta$-glucosidases and

Table 2 The reported filamentous fungi with nitrilase activity in the previous literature

\begin{tabular}{|c|c|c|c|c|c|c|c|}
\hline Filamentous fungi & $\begin{array}{l}\text { Formation } \\
\text { type }\end{array}$ & $\begin{array}{l}\text { Molecular } \\
\text { weight (kDa) }\end{array}$ & $\begin{array}{l}\text { Optimum } \mathrm{pH} / \\
\text { temperature }\left({ }^{\circ} \mathrm{C}\right)\end{array}$ & $\begin{array}{l}\text { Stability } \mathrm{pH} / \\
\text { temperature }\left({ }^{\circ} \mathrm{C}\right)\end{array}$ & Substrate specificity & $K m(\mathrm{M})$ & Reference \\
\hline A. furmigatus & Inducible & - & - & - & a-Aminophenylacetonitrile & - & {$[70]$} \\
\hline F. oxysporum f sp. melonis & Inducible & 550 & $-/ 40$ & 6-11 / below 40 & Aromatic nitriles & $1.7 \times 10^{-2}$ & {$[64]$} \\
\hline A. niger $\mathrm{K} 10$ & Inducible & $>650$ & $8 / 45$ & 7.2-9 / below 30 & Aromatic nitriles & $4.7 \times 10^{-3}$ & {$[66]$} \\
\hline F. solani $\mathrm{O} 1$ & Inducible & 580 & $8 / 50$ & $7-9 / 35-50$ & Aromatic nitriles & $1.4 \times 10^{-3}$ & {$[67]$} \\
\hline F. solani IMI 196840 & Inducible & 550 & $8 / 45$ & 7.8-9.1 / below 50 & Aromatic nitriles & - & {$[63,69]$} \\
\hline
\end{tabular}

Note: "-" indicates no data available. 
$\alpha$-hydroxynitrilases [22]. Therefore, cyanide detoxification is necessary for plant growth. Lotus japonicus contains two cyanogenic $\alpha$-hydroxynitrile glycosides. Piotrowski et al. successfully cloned a nitrilase gene from $L$. japonicus, which displayed remarkable $\beta$-cyanoalanine hydrolyzing activity [22]. The nitrilase heterodimers were probably involved in the cyanogenic glucoside catabolism of sweet almonds and sorghum [84]. Furthermore, several additional plant nitrilases have evolved, which might be involved in the catabolism of cyanogenic glycosides [83] or in the catabolism of glucosinolates $[78,80,81]$.

\section{Nitrilase obtaining manners}

In all these cases of biocatalytic applications, improving the catalytic properties of existing enzymes or finding the potential of new ones is strongly demanded. Considering the new ones, they should first be obtained from the natural environment before an in-depth study and practical application. Thus, various pathways to acquire the target nitrilase were introduced. According to Yamada, one of the leading founders in the area of industrial biocatalysis, searching for better biocatalysts to improve productivity is still of great significance even when the industrial process functions well [85]. Hence, the importance of continuing the screening for microorganisms of interest always remains.

\section{Conventional screening}

Traditionally, nitrilase-producing microorganisms were screened in a selective medium with nitriles as the sole source of nitrogen or/and carbon, where only the strains harboring nitrile-degrading activity can grow. For example, Shen et al. isolated a novel $A$. nitroguajacolicus from soil samples with acrylonitrile as the sole nitrogen source, which can convert acrylonitrile to acrylic acid [57]. An enrichment medium, with glucose as the carbon source and phenylacetonitrile as the sole source of nitrogen, was applied to select the acidotolerant nitrilase-producing yeasts. A black yeast was isolated and identified as an E. oligosperma strain [21]. A fungal $F$. solani strain was isolated by Harper from the bromoxynil-treated soil with benzonitrile as sole carbon and nitrogen source and is a promising degrader of nitrilic herbicides [63].

Nitrilase activity assay is based on $\mathrm{NH}_{3}$ analysis, which is equimolarly produced with acids from the bioconversion reaction. $\mathrm{NH}_{3}$ determination is usually performed using the phenol-hypochlorite reaction [86], as well as the $\mathrm{CoCl}_{2}$-based [87], Nessler [88], and Indophenol methods [89]. Mass spectrometry, nuclear magnetic resonance (NMR) spectroscopy, liquid and gas chromatography are often used as the quantitation methods for substrate and product assays [90].

\section{High throughput screening}

Conventional screening is an effective method for obtaining nitrilase-producing microorganisms; however, it is a time-consuming and tedious work. Furthermore, quantitative detection methods are expensive and slow [90]. Consequently, the high-throughput screening method was developed and has gained increasing popularity in the search for potential biocatalysts in recent years. The assays are based on fluorogenic and chromogenic substrates, or $\mathrm{pH}$ indicator methods. Santoshkumar et al. recently developed a $\mathrm{pH}$ indicator method to rapidly screen aliphatic nitrile-degrading bacteria, and found that some indicators, such as phenol red, bromothymol blue, and phenolphthalein, were sensitive to the liberation of ammonia from the nitrile-utilizing bacteria [91]. He et al. first proposed a simple and accurate high-throughput screening method based on ferric hydroxamate spectrophotometry. They showed that the accuracy of this method for determining carboxylic acid was extremely high compared with the HPLC-based method [92]. A novel time-resolved luminescent probe of $o$-hydroxybenzonitrile derivatives was utilized in highthroughput detection of nitrilase activity [93]. Higher sensitivity with this probe was observed because the time-resolved property of the luminescence can reduce the background from other proteins. A rapid and sensitive fluorometric method was proposed by Banerjee et al., which employed o-phthaldialdehyde-2-mercaptoethanol with nitrilase reaction solution to form a fluorochrome [94], and the results further supported the established Berthelot method. Therefore, other simple, sensitive, and/or accurate assays should be developed to display the importance of high-throughput screening.

\section{Structure and catalytic properties of nitrilase}

The superficial understanding on the protein structure and catalytic properties of nitrilase is the main barrier for molecular manipulation, such as rational design. Therefore, the determination of the exact protein structure, and the catalytic mechanism of nitrilase comes into prominence, with the rising requirement for molecular operations.

According to Brenner and his colleagues, the structure of the nitrilase protein is a novel $\alpha-\beta-\beta-\alpha$ sandwich fold, with a triad of residues, Glu-Lys-Cys (Figure 2), which is essential in the function of its active site and enhances the performance of nitrilase [95]. The results achieved by Sewell's group confirmed that the nitrilase from $R$. rhodocrous $\mathrm{J} 1$ have three homo-oligomeric structural forms: a dimer, a $480 \mathrm{kDa}$ complex, and an extended helix [96]. The J1 nitrilase model was generated, and this enzyme has an extended C-terminus and two significant insertions that intersperse in the spiral oligomer and lead to spiral elongation. Meanwhile, the 3D structures 


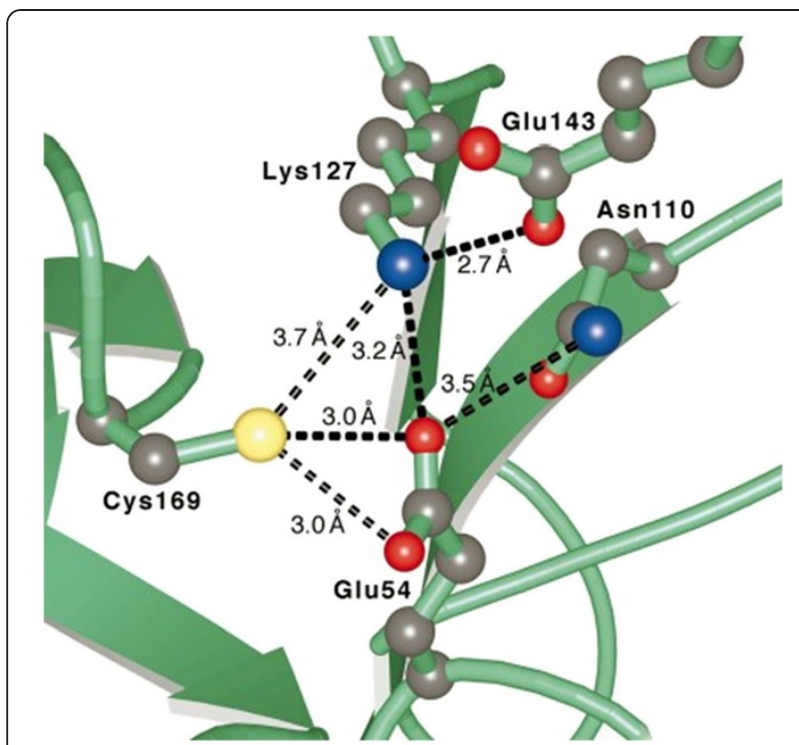

Figure 2 Putative nitrilase active site [95]. The related residues of Glu54, Lys127 and Cys169 were considered functionally important as a catalytic triad in the nitrilase superfamily.

of these helical homooligomers were determined by electron microscopy. The 3D stain envelope was consistent with cyanide dihydratase from $P$. stutzeri, a member of the nitrilase superfamily $[96,97]$. Nitrilase from G. pallidus RAPc8 showed various structural forms, such as crescent-like, c-shaped, circular, and "figure-8" shapes through electron microscopy and image classification [59]. Far-UV circular dichroism (CD) spectroscopy was employed to determine the secondary protein structure of nitrilases from F. solani O1, and F. solani IMI 196840 [69]. Both nitrilases harbored almost identical contents in their secondary structure, consisting of $30 \% \alpha$-helix, $21 \% \beta$-sheet, $16 \%$ turn, and 33\% other structures.

The catalytic properties of the nitrilase transformation reaction are widely investigated by several groups. In the early 1960s when the first nitrilase was found by Mahadevan et al. [19], it has postulated that the nitrile carbon bearing a fractional positive charge was subjected to a nucleophilic attack, probably by one of the two $\mathrm{SH}$ groups on the nitrilase. The resulting imine was then hydrolyzed to corresponding ketone while having $\mathrm{NH}_{3}$ as a by-product. Acyl-enzyme was then hydrolyzed by the addition of $\mathrm{H}_{2} \mathrm{O}$, and finally liberated the carboxylic acid along with the regenerated enzyme. On the same year, Hook and Robinson demonstrated that a similar mechanism was also responsible for the ricinine hydrolysis through the ricinine nitrilase [28]. The proposed mechanism has been widely accepted by researchers to date (Figure 3) [13,98,99]. However, recent studies demonstrated that amide compounds might also be formed in the course of nitrile hydrolysis by nitrilase. Piotrowski et al. reported for the first time the NHase activity shown by the nitrilase from Arabidopsis thaliana, which can convert $\beta$-cyano- $\mathrm{L}$-alanine into aspartic acid and asparagine (with $>60 \%$ asparagine formation) [79]. Hence, the authors predicted that this reaction was contributed by a new type of NHase activity, different from the known mechanism of "classical" NHases. This NHase activity is probably attributed to the advanced release of an enzyme-bound substrate after the addition of the first $\mathrm{H}_{2} \mathrm{O}$. Subsequently, amide was produced based on the belated delivery of the second $\mathrm{H}_{2} \mathrm{O}$. Afterward, the significant amide formation under nitrilase control was studied in terms of steric requirements and electron density [100], which showed that the absolute $\alpha$-carbon configuration in the substrate had a great effect on the acid/amide ratio. Furthermore, a low temperature and increased $\mathrm{pH}$ prompted the reaction towards amide. Meanwhile, the electron-withdrawing substituents at the $\alpha$-position tended towards amide formation.

Some nitrilases possessed a subunit size between $30 \mathrm{kDa}$ and $45 \mathrm{kDa}$, and must form heterocomplexes to gain catalytic activity. Poaceae nitrilase (NIT4 enzyme) activity was entirely derived from the formation of heteromeric complexes [83]. This was different from other plant nitrilases. The complexes were consisted of two NIT4 isoforms (NIT4A and NIT4B). Stevenson et al. found that the binding of an aromatic ring in the substrates can lead to the aggregation of the Rhodococcus ATCC 39484 nitrilase [101]. Such substrate-induction activated the enzyme

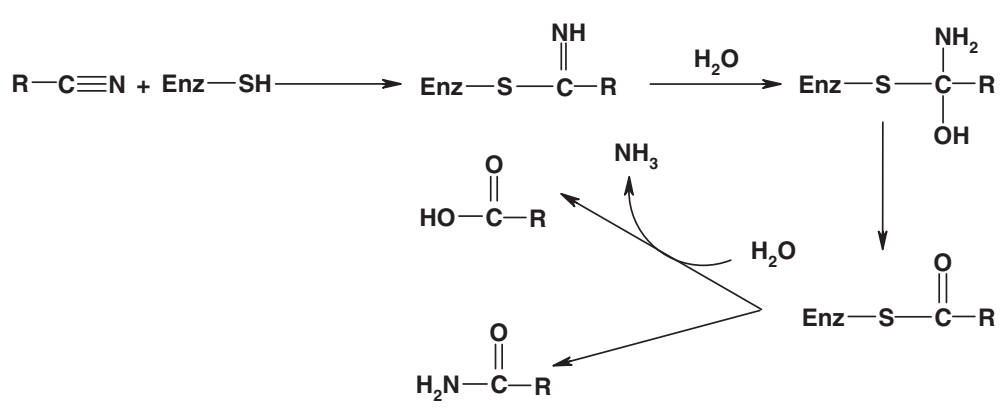

Figure 3 Proposed mechanism for nitrilase-mediated biocatalysis. 
by the formation of a $560-\mathrm{kDa}$ complex through the association of the $47-\mathrm{kDa}$ monomer. HPLC gel filtration can detect an association/dissociation equilibrium. The same aspect was also observed for the $R$. rhodochrous $\mathrm{J} 1$ nitrilase, where a number of salts and organic solvents can improve the association [102]. Enzyme forms were unstable during nitrilase assembly and nitrilase activities were only detected in the dimer and decamer.

\section{Factors influencing nitrilase production and its bioconversion}

Several factors conspicuously influence the enzyme activity or biomass formation, including culture conditions, such as carbon source, nitrogen source, inducer and metal ion, and the bioconversion conditions, such as temperature, $\mathrm{pH}$, enzyme modifier, and organic solvent.

\section{Factors that influence nitrilase production Carbon and nitrogen source}

Commonly, carbon and nitrogen sources have remarkable effects on enzyme yield. These sources are significant in cell proliferation and cellular enzyme biosynthesis [103]. Furthermore, in some situations, the nature and concentration of these nutrients regulated enzyme formation through physiological events, such as the catabolic repression from glycerol, glucose, and fructose. A foremost example was $P$. putida MTCC 5110, in which little nitrilase production was obtained when glycerol was utilized as the carbon source, although it supported an excellent biomass [104]. Sodium acetate, starch, glucose, and mannitol are the optimum carbon sources, whereas peptone, yeast extract, and casamino acid are the optimum nitrogen sources for nitrilase formation in Alcaligenes sp., $A$. faecalis, A. nitroguajacolicus, P. putida, Rhodococcus sp., E. oligosperma, as reported previously [61,105-107].

\section{Inducer}

To the best of our knowledge, most nitrilases are inducible by substrates, products, and their analogs, as shown in Tables 1 and 2. However, little is known about constitutive nitrilases, aside from those of Brevibacterium R312, $K$. ozaenae, B. subtilis ZJB-063, and Alcaligenes sp. ECU0401 as reported previously $[30,53,105,108]$. In addition, the multi-enzyme system including nitrilase and NHase/ amidase in Amycolatopsis sp. IITR215 is constitutive [109]. In general, certain nitriles, amides, and carboxylic acids function as nitrilase inducers. $\varepsilon$-Caprolactam, first found as a powerful inducer of the $R$. rhodochrous J1 nitrilase, also results in the effective induction in some other Rhodococcus strains [110]. Nevertheless, Rhodococcus sp. NDB 1165 nitrilase was induced by propionitrile [49]. Benzonitrile was used as the inducer of nitrilase from $P$. aeruginosa 10145, in which cell growth was inhibited by the addition of benzonitrile at the beginning and thus the inducer was added after cultivation for $24 \mathrm{~h}$ [51]. The effects of different inducers on substrate specificity of A. faecalis MTCC 10757 were investigated by Nageshwar et al., and acrylonitrile was the most preferred inducer and substrate [61]. With regard to fungal nitrilase, 2-cyanopyridine was reputed a universal inducer in filamentous fungi, such as those from the genera of Aspergillus, Fusarium, and Penicillium [20]. The total nitrilase activity of F. solani O1, in the presence of 2-cyanopyridine, can be enhanced by a hundred fold compared with other inducers [111]. However, our experiments demonstrated that caprolactam was also a useful inducer for fungal nitrilase from the Fusarium genus [86]. Detailed work on caprolactam induction was attempted to further improve the fungal nitrilase formation.

\section{Metal ion}

Metal ions, such as $\mathrm{Fe}^{3+}$ or $\mathrm{Co}^{2+}$, were essential for the formation of NHases [112]; however, nitrilases do not require any metal ions as co-factor for their activity. These nitrilases have the catalytic cysteine residues at or near their active site, as forementioned. As yet, few studies reported the effect of metal ions on nitrilase production. $\mathrm{Co}^{2+}, \mathrm{Hg}^{2+}$, and $\mathrm{Ag}^{+}$may inhibit the specific activity of nitrilase, and $\mathrm{Cu}^{2+}$ can hinder cell growth. Such an occurrence can be found in $R$. rhodochrous J1 [113] and $P$. putida MTCC 5110 [104]. Nevertheless, a reverse occurrence was unusually observed in Alcaligenes sp. ECU0401, in which $\mathrm{Cu}^{2+}$ supported both a higher biomass and more nitrilase production [105]. However, the exact mechanism for the enhancement of nitrilase activity by metal ions is still unclear. Although most metal ions promoted neither biomass nor enzyme formation in the previous limited studies, investigation on the effects of metal ions is still needed.

\section{Factors that influence nitrilase bioconversion Temperature and $\mathrm{pH}$}

Temperature and $\mathrm{pH}$ often affect the structure and the nature of an enzyme, thereby further influence enzyme activity. Enzymatic reactions are generally performed under relatively mild conditions. Tables 1 and 2 showed that the optimum $\mathrm{pH}$ and temperature for the bioconversion reaction by nitrilase from most bacteria and fungi are placed in the $\mathrm{pH}$ range of 7.0-8.0 and in the temperatures ranging from $30^{\circ} \mathrm{C}$ to $55^{\circ} \mathrm{C}$, respectively. Few nitrilases can function under extreme conditions. An alkali resistant nitrilase from Pseudomonas sp. 13 was characterized [31] and proved to have the optimum $\mathrm{pH}$ of 9.5 in the presence of $10 \mathrm{mM}$ 2-mercaptoethanol. Rustler et al. [74] demonstrated that E. oligosperma nitrilase can hydrolyze the $\alpha$-hydroxynitriles under acidic conditions. 
Temperature is one of the most crucial factors for enzymatic reaction rate. The enzymatic reaction rate increases with the increase in reaction temperature because the molecular free energy increases resulting from the rising temperature, which can make more efficient collisions between the molecules [57]. On the contrary, excessively higher temperature leads to protein denaturation and thus the loss of enzyme activity. Thermoactive nitrilase from the anaerobic archaeon $P$. abyssi that grows optimally at $100^{\circ} \mathrm{C}$, is an exception [47].

\section{Stability}

Operational stability was proven as one of the key requirements for biocatalyst on a commercial scale. The stability of nitrilases has been widely investigated, including their thermostability and $\mathrm{pH}$ stability. The half-life is an important evaluation index of biocatalyst stability. Previous studies revealed that the nitrilases from P. putida [114], Microbacterium paraoxydans [114], M. liquefaciens [114], A. nitroguajacolicus [57], and A. faecalis [60] had halflives of $27.3 \mathrm{~h}, 1.7 \mathrm{~h}, 5.4 \mathrm{~h}, 157.6 \mathrm{~h}$, and $14 \mathrm{~d}$ at $30^{\circ} \mathrm{C}$, respectively. Remarkably, a highly thermostable nitrilase, with a half-life of $25 \mathrm{~h}$ at $70^{\circ} \mathrm{C}, 9 \mathrm{~h}$ at $80^{\circ} \mathrm{C}$, and $6 \mathrm{~h}$ at $90^{\circ} \mathrm{C}$, was purified from $P$. abyssi [47]. The half-lives of fungal nitrilase from $F$. solani $\mathrm{O} 1$ were $178 \mathrm{~h}$ and $4.4 \mathrm{~h}$ at $28^{\circ} \mathrm{C}$ and $45^{\circ} \mathrm{C}$, respectively [111]. Meanwhile, our studies observed the half-lives of $231.1 \mathrm{~h}$ and $72.9 \mathrm{~h}$ at $30^{\circ} \mathrm{C}$ and $40^{\circ} \mathrm{C}$ for Gibberella nitrilase, respectively (data not shown). Nonetheless, Goldlust et al. [64] revealed that heating for $10 \mathrm{~min}$ at more than $40^{\circ} \mathrm{C}$ would result in the inactiviation of nitrilase from $F$. oxysporum $\mathrm{f}$ sp. melonis.

Similarly, most nitrilases displayed low stability and rapidly became inactivated in extreme $\mathrm{pH}$ conditions. The stability of the nitrilase from P. putida MTCC 5110 was determined at different $\mathrm{pH}$ values ranging from 6.5 to 8.0 [46]. Nitrilase stability of this enzyme was maintained at $\mathrm{pH} 7.0$ with a half-life of $110 \mathrm{~min}$, but rapidly decreased as $\mathrm{pH}$ varied above and below $\mathrm{pH}$ 7.0, and exhibited the half-lives of 36, 87, and $53 \mathrm{~min}$ at $\mathrm{pH}$ 6.5, 7.5, and 8.0, respectively. However, recombinant nitrilase from Alcaligenes sp. ECU0401 showed excellent stability at $\mathrm{pH} 7.0$ and 8.0, with half-lives of 382 and $43 \mathrm{~h}$, respectively [54]. Therefore, such a robust biocatalyst may have great potential for its industrial application in nitrile biocatalysis.

A concentrated enzyme solution was adopted by Griengl et al. to synthesize cyanohydrins with hydroxynitrile lyase in two-phase systems to improve the enzyme stability [115]. On the other hand, immobilization, as discussed below, is favorable to biocatalyst stability probably because immobilized cells were protected against the toxic effects of the substrates [15].

\section{Organic solvent}

Organic solvents are a kind of co-solvent, which have been recognized to increase the solubility of substrates or products in the bioconversion reaction. The enzymatic reactions in organic solvents, such as the lipasemediated reaction, were extensively reported. In recent years, the degree of resistance to organic solvents for nitrilase has also been frequently investigated because of the poor solubility of most nitriles. Heinemann et al. observed the presence of methanol increased the reaction rate of the recombinant nitrilase from Synechocystis sp. PCC6803 [116]. The maximal conversion of this nitrilase was achieved in the presence of $40 \%(\mathrm{v} / \mathrm{v})$ hexadecane. Previous studies on F. solani O1 suggested that the nitrilase was fairly stable in selected organo-aqueous media [67]. More than half of its initial activity was maintained in the presence of $5 \%-50 \%$ of n-hexane or $n$ heptane, or $5 \%-15 \%$ of xylene or ethanol. Moreover, full activity of Pseudomonas sp. DSM 11387 nitrilase was retained in the presence of $50 \%(\mathrm{v} / \mathrm{v})$ hexadecane [117]. In addition, the presence of large amounts of organic solvents in the oxynitrilase mediated transformation reaction was reported to suppress the reversible chemical reaction [118]. The organic solvent increased the tendency of the chemical equilibrium to synthesize more products.

\section{Enzyme modifier}

Numerous enzyme modifiers, including inhibitors, stabilizers and metal ions, obviously affect enzyme activity. Nitrilases have catalytically conserved cysteine residues that contain the thiol group. Thiol-binding reagents, such as $\mathrm{Cu}^{2+}, \mathrm{Ag}^{+}, \mathrm{Hg}^{2+}$, N-ethylmaleimide, 5, 5-dithiobis (2-nitrobenzoic acid), iodoacetamide, iodoacetic acid, $p$-chloromercuribenzoate, and $p$-hydroxymercuribenzoate, were proven strong inhibitors of nitrilase activity in literature $[39,46,47,53,69]$. High sensitivity to these reagents indicates the importance of thiol group in the catalytic activity. Carbonyl reagents such as hydroxylamine, phenylhydrazine, and semicarbazide, were reported to have no significant inhibitory effect on nitrilases from P. putida MTCC 5110 [46] and R. rhodochrous PA-34 [39], but inhibited nitrilase activities of $R$. rhodochrous J1 [34] and A. faecalis JM3 [36]. Previous study showed that metal chelating agents, such as ethylene diamine tetraacetic acid (EDTA), sodium azide, 8hydroxyquinoline, and $o$-phenanthroline, had little or no influence on nitrilase activity $[46,47,55,57]$. However, EDTA greatly activated the Alcaligenes sp. nitrilase activity at $1 \mathrm{mM}$, but had a slight inhibitory effect at $5 \mathrm{mM}$ [54]. This phenomenon further confirmed that nitrilases do not require metal ions as co-factor. Moreover, the effect of reducing agents, including dithiothreitol, 2mercaptoethanol, D-cysteine, L-cysteine, ascorbic acid, 
and reduced glutathione on enzyme activity was determined, and their positive impact on nitrilase activity was observed in $P$. abyssi [47]. However, these agents had no advantageous effects on the activity of nitrilases from Pseudomonas strains [46,55]. In addition, dithiothreitol caused the inhibition of nitrilase activity from filamentous fungi, such as F. solani $\mathrm{O} 1$ and $A$. niger K10 [66,67].

\section{Substrate and product concentration}

Nitrile compounds are highly toxic and harmful to the nitrilase protein, which makes the substrate concentration become one of the limiting factors for the biotransformation process. However, from another standpoint, a higher substrate concentration around the enzyme produces a higher reaction rate because of chemical equilibrium [119]. In addition, at least $\geq 50 \mathrm{~g} \cdot \mathrm{L}^{-1}$ product concentration and excellent gram product/gram catalyst yield are necessary for industrial scale [120]. Almatawah et al. determined the effects of substrate and product concentration on the bioconversion of 3-cyanopyridine into nicotinic acid by $B$. pallidus Dac521 nitrilase [121]. The results demonstrated that both 3-cyanopyridine and nicotinic acid inhibited the hydrolysis reaction at concentrations greater than $200 \mathrm{mM}$. $(R, S)$-mandelonitrile is hypertoxic; however, no substrate inhibition of $A$. faecalis ZJUTB10 nitrilase was observed under the $(R, S)$-mandelonitrile concentration from $10 \mathrm{mM}$ to $50 \mathrm{mM}$ [60]. Furthermore, the recombinant nitrilase of Alcaligenes sp. showed a high substrate tolerance and was capable of withstanding $200 \mathrm{mM}(R, S)$-mandelonitrile as substrate [122].

\section{Separation and purification of nitrilase}

Nitrilases are typically intracellular enzymes that are fragile and susceptible to outside environment. Therefore, purification of nitrilases from microbial cells is more difficult than extracellular enzymes. All purification procedures were performed under $4^{\circ} \mathrm{C}$.

Cell disruption was performed by ultrasonication [38], high-pressure homogenization [46], grinding in mortar [66], or disintegration with glass beads [63] to prepare cell-free extracts. The cell lysate was centrifuged to remove cell debris. In F. solani O1 nitrilase, up to $90 \%$ of the whole-cell activity was recovered in cell-free extract using an extraction buffer supplemented with $0.8 \mathrm{M}$ ammonium sulfate. A large ratio of contaminating cellular protein was removed during the extraction [67]. Furthermore, the purification process was performed using ammonium sulfate fractionation and various types of column chromatography techniques. Table 3 lists some reported information on the purification procedures of nitrilase.

\section{Immobilization of nitrilase}

Immobilization of whole cells and purified enzymes can make the biocatalytic process more economical. To our knowledge, most industrial processes for nitrile biocatalysis were performed using immobilized biocatalysts. However, little information is reported on the biotransformation of nitriles by free cells in commercial scale.

The availability of immobilized biocatalysts being recycled can greatly reduce the operational cost in the production process. Compared with the free catalysts, separating the immobilized biocatalysts from the bioconversion reaction mixture is easier, making the repeated batch operations possible and simple. The activity of immobilized lipase in sol-gel was enhanced by up to 100-fold compared with the free ones [124]. Moreover, immobilization improved the operational stability, and immobilized cells were found to hydrolyze a wider range of nitriles than free cells [125]. Hydrolysis may have contributed to the protective role of immobilized cells against the toxic effect of nitrile substrates. A greater reaction rate than that of free cells was observed for immobilized A. faecalis MTCC 126 nitrilase at $65^{\circ} \mathrm{C}$ [126]. This nitrilase of free cells was extremely unstable, and thus it was conjectured that its thermostability increased significantly after immobilization. Meanwhile, immobilized Candida guilliermondii CCT 7207 cells degraded some nitriles that cannot be utilized by the corresponding free cells [127].

A wide variety of immobilization methods and materials were reported in numerous studies [126-128]. The immobilization methods mainly include entrapment, cross-linking, adsorption, and covalent bonding. The immobilization materials include polyvinyl alcohol, DEAE cellulose, alginate $\left(\mathrm{Sr}^{2+}, \mathrm{Ba}^{2+}, \mathrm{Na}^{+}, \mathrm{Al}^{3+}, \mathrm{Ca}^{2+}\right.$, and so on), alumina, carrageenan gels, and polyacrylamide. Notwithstanding the immobilization procedure can lead to the partial loss of enzyme activity, numerous studies on nitrilase-mediated biocatalysis by immobilized catalysts were carried out. The $P$. putida nitrilase activity of cross-linked enzyme aggregate preparation remained stable for $75 \mathrm{~h}$ at $4^{\circ} \mathrm{C}$, whereas the free enzyme lost $90 \%$ nitrilase activity at the same temperature for $75 \mathrm{~h}$ [129]. Liu et al. used polyvinyl alcohol and alginate $\left(\mathrm{Na}^{+}\right) \mathrm{co}-$ polymer to entrap the recombinant cells harboring $A$. facilis nitrilase [128]. The entrapped cells were firstly utilized in iminodiacetic acid preparation from iminodiacetonitrile and showed moderately good operation stability. The immobilized biocatalyst can be reused for 10 batches, whereas the free cells completely lost the activity after 9 batches. Immobilized Streptomyces nitrilase in a cheap matrix (agar-agar) was applied in the biotransformation of acrylonitrile at $50^{\circ} \mathrm{C}$ in a batch operation mode [56]. The immobilized cells can be reused for 25 cycles, with only an approximately $20 \%$ enzyme activity loss. Immobilization using alginate resulted in efficient recycling of the $A$. faecalis nitrilase, retaining almost $100 \%$ activity up to 30 consecutive cycles 
Table 3 Reported purification procedures of nitrilase

\begin{tabular}{|c|c|c|c|c|c|}
\hline Organisms & Purification process ${ }^{a}$ (In order) & $\begin{array}{l}\text { Purification } \\
\text { fold }\end{array}$ & $\begin{array}{l}\text { Specific } \\
\text { activity }\left(\mathrm{U} \cdot \mathrm{mg}^{-1}\right)\end{array}$ & $\begin{array}{l}\text { Yield } \\
(\%)\end{array}$ & Reference \\
\hline Pseudomonas sp. & $\begin{array}{l}\text { DEAE-cellulose; Ammonium sulfate fractionation; } \\
\text { Starch electrophoresis }\end{array}$ & 400 & 12 & 14 & [28] \\
\hline Nocardia sp. NCIB 11215 & DEAE-cellulose; Ammonium sulfate fractionation; Sephadex G-200 & 15.82 & 1.74 & 9.1 & [123] \\
\hline Pseudomonas sp. 13 & $\begin{array}{l}\text { Ethanol fractionation; Ammonium sulfate fractionation; } \\
\text { DEAE-cellulose; } 1^{\text {st }} \text { crystallization; } 2^{\text {nd }} \text { crystallization }\end{array}$ & 656 & 3280 & 21 & [31] \\
\hline F. oxysporum f sp. melonis & DEAE-Sephacel; TSK-phenyl 5 PW & 39.72 & 143 & 50 & [64] \\
\hline R. rhodochrous $\mathrm{K} 22$ & $\begin{array}{l}\text { DEAE-Sephacel; Ammonium sulfate fractionation; } \\
\text { Phenyl-Sepharose CL-4B; Cellulofine GCL-2000 superfine }\end{array}$ & 8.3 & 0.737 & 9.08 & [40] \\
\hline Acinetobacter sp. AK 226 & $\begin{array}{l}1^{\text {st }} \text { DEAE-cellulose; } 1^{\text {st }} \text { Hydroxyapatite; } 2^{\text {nd }} \text { DEAE-cellulose; } \\
2^{\text {nd }} \text { Hydroxyapatite; Sephacryl S- } 400\end{array}$ & 4.41 & 0.156 & 20.1 & [37] \\
\hline A. faecalis ATCC 8750 & $\begin{array}{l}\text { Ammonium sulfate fractionation; Phenyl-Sepharose } \\
C L-4 B ; \text { DEAE-cellulose }\end{array}$ & 29.0 & 3.10 & 17.9 & [38] \\
\hline C. testosteroni sp. & Q-Sepharose; Superdex 200; Hydroxyapatite & 60 & 68 & 79 & [35] \\
\hline R. rhodochrous NCIMB 11216 & $\begin{array}{l}\text { Ammonium sulfate precipitation; Anion-exchange FPLC; } \\
\text { Sepharose Q; Suparose } 12 \text { HR 10/30 }\end{array}$ & 62 & 10.6 & 9.5 & [43] \\
\hline R. rhodochrous PA-34 & $\begin{array}{l}\text { Ammonium sulfate fractionation; } 1^{\text {st }} \text { Sephacryl S-300 HR; } 2^{\text {nd }} \\
\text { Sephacryl S-300 HR; DEAE Toyopearl 650S }\end{array}$ & 14.10 & 3.52 & 34.8 & [39] \\
\hline P. fluorescens DSM 7155 & Phenyl-Sepharose FF; Mono Q; Superose 12 & 259 & 90 & 10 & [44] \\
\hline A. facilis $72 \mathrm{~W}$ & Ammonium sulfate precipitation; Sephadex G-25; Q-Sepharose & 10.5 & 21 & 65 & [48] \\
\hline P. putida MTCC 5110 & $\begin{array}{l}\text { Ammonium sulfate fractionation; Superdex 200; Q-sepharose; } \\
\text { Phenyl sepharose }\end{array}$ & 35.01 & 3.26 & 10.15 & [46] \\
\hline A. niger $\mathrm{K} 10$ & Ammonium sulfate precipitation; Sephacryl S-200; Q-Sepharose & 18.7 & 91.6 & 24.3 & {$[66]$} \\
\hline P. abyssi GE5 & Heat treatment; Q-Sepharose & 23.85 & 141.9 & 88 & [47] \\
\hline F. solani $\mathrm{O} 1$ & Phenyl sepharose; Sephacryl S-200; Q-Sepharose & 9.9 & 156 & 25.9 & {$[67]$} \\
\hline F. solani IMI 196840 & Phenyl sepharose; Sephacryl S-200; Q-Sepharose & 20.3 & 144.0 & 26.9 & [69] \\
\hline
\end{tabular}

${ }^{a}$ Purification process only listed the adopted column chromatography techniques after cell-free extracts preparation.

compared with only nine cycles for free cells [126]. Also, the recycle efficiency can be further increased to 40 batch reactions through cross-linking of alginate beads using glutaraldehyde and polyethylene imine.

\section{Molecular cloning and modification of nitrilase gene Gene cloning and heterologous expression}

Enzyme reengineering becomes a common process with the development of modern molecular biology and the requirement of more efficient biocatalytic reaction. Natural biocatalysts often cannot meet the expectations of scientists and engineers with respect to some enzymatic properties. Therefore, constructing a recombinant enzyme combining with some gene manipulation, such as direct evolution, would provide the possibility to further meet the synthetic application requirement with high efficiency. Several nitrilase genes are presently cloned from various organisms and introduced into appropriate host strains.

As early as 1987, Stalker et al. successfully cloned the gene locus $(b x n)$ that encode the bromoxynil-specific nitrilase in $K$. ozaenae [108], and this $b x n$ gene was ligated with pUC18 vector and overexpressed in E. coli
71-18. Shortly thereafter, the first plant gene from $A$. thaliana coding nitrilase was identified, and an $A$. thaliana nitrilase cDNA was isolated, characterized, sequenced, and functionally expressed [130]. On the other hand, Pekarsky et al. cloned and characterized tumor suppressor genes from D. melanogaster and C. elegans [131], and their fusion protein showed homology to bacterial and plant nitrilases.

Kobayashi and his co-workers cloned and sequenced the gene for nitrilase from $A$. faecalis JM3 and expressed the active enzyme in E. coli [132]. A 35\% increase in the specific activity, together with an obvious decrease of the $\mathrm{Km}$ value for thiophene-2-acetonitrile, was observed. In addition, the study strongly proved that Cys-163, one of the five cysteine residues in the nitrilase, was crucial for the function of the active site. The same hypothesis was also supported by the experimental results for recombinant nitrilases from C. testosteroni sp. [35] and $R$. rhodochrous K22 [133]. A regioselective aliphatic nitrilase from A. facilis $72 \mathrm{~W}$ was cloned and overexpressed under the control of strong T7 promoter in the pET-3c vector [48]. The engineered nitrilase displayed a 15 -fold higher enzyme activity than the native $72 \mathrm{~W}$ strain; 
however, the increase of specific activity was approximately three fold. The protein engineering combined with fermentation optimization for this recombinant nitrilase of $A$. facilis was employed to improve catalytic efficiency for glycolic acid production, and the specific enzyme activity was increased up to 125-fold [134]. Zhu et al. cloned and overexpressed a novel nitrilase gene blr3397 from B. japonicum USDA 110 in E. coli [135], which was proven extremely specific towards hydrocinnamonitrile (about $9.99 \mathrm{U} \cdot \mathrm{mg}^{-1}$ protein). Mueller et al. cloned and expressed a thermoactive nitrilase from $P$. abyssi in $E$. coli [47]. The recombinant enzyme was proven highly thermostable, with a half-life of $6 \mathrm{~h}$ at $90^{\circ} \mathrm{C}$.

The heterologous expression of genes that encode nitrilases from filamentous fungi has scarcely been investigated. Until recently, a fungal nitrilase gene of $A$. niger K10 was amplified from the cDNA library and ligated into expression vectors $\mathrm{pET}-30 \mathrm{a}(+)$ (Novagen) and pRSET B (Invitrogen). A two fold increase was observed in the specific activity of recombinant nitrilase (Nit-ANigRec) expressed in E. coli BL21-Gold(DE3) (pOK101/pTf16) [68]. Moreover, genome mining was performed to search for fungal nitrilases [136], and synthetic genes of putative nitrilase from Gibberella, Neurospora, and Aspergillus were expressed in E. coli.

\section{Directed evolution}

The commercial availability of biocatalysts is a limiting factor for their practical application. Heterologous expression of nitrilase gene in host cells becomes a routine manner. In recent years, directed evolution was rapidly emerging as a novel and powerful strategy for the improvement of the catalytic properties of enzymes, such as specific activity, substrate tolerance, and thermostability. This technique mainly include two steps: establishing random mutation libraries through error-prone polymerase chain reaction (EP- PCR) as well as DNA recombination and screening of libraries using various chemical methods. Schreiner et al. used EP-PCR with recombination of beneficial mutations to improve both specific activity of nitrilase from A. faecalis JM3 and its fitness at low $\mathrm{pH}$ values [137]. The nitrilase activity of individual clones from mutation libraries was determined in a 96well microtiter plate through the colorimetric reaction of the Berthelot method. A variant with eight fold improvement of the specific activity for 2-phenylpropionitrile at $\mathrm{pH} 7.5$ was ultimately obtained. The sequence analysis showed that this variant carried seven mutations. Furthermore, another variant (pHNIT45) was proven to harbor high activity at $\mathrm{pH}$ values as low as $\mathrm{pH} 4.5$. pHNIT45 can fully convert $10 \mathrm{mM}(R)-2-\mathrm{Cl}$-mandelonitrile into $(R)$-2-Cl-mandelic acid stoichiometrically, with enantiomeric excess $(e e)>99 \%$ within $10 \mathrm{~min}$.

\section{Site-directed mutagenesis}

Site-directed mutagenesis for nitrilase modification at the gene level attracted increasing interest in some recent studies. Point mutations, even a single amino acid exchange, may create a significant impact on specific activity, substrate specificity, selectivity, amide formation capacity, and amide:acid ratio. Tyr-142 in the nitrilase gene from $R$. rhodochrous ATCC 33278 is an important amino acid residue for substrate specificity [138]. The mutants that contain non-polar aliphatic amino acid at this position were specific only for aromatic nitriles but not for aliphatic ones. The substrates hydrolysis probably needed a conjugated $\pi$-electron system in nitriles or Tyr-142 residue. Ala-165 and Cys-163 residues in the $P$. fluorescens EBC191 nitrilase, which was in close proximity to the cysteine residue in the catalytic center, were identified and proven responsible for the enantioselectivity and amide formation [139]. Especially, the mutation C163Q resulted in an obvious increase in amide formation, but reduced enzyme activities towards $(R)$-mandelonitrile. Moreover, deletion mutants with 47-67 C-terminal amino acids missing displayed reduced activities, increased amide formation and changes of enantiospecificity [97]. Thus, the combined mutants of these mutations were constructed and the results demonstrated that the combination led to a 1.5-fold increase in mandeloamide formation and exhibited the highest NHase activity among all the variants of $P$. fluorescens nitrilase [140]. Petříčková et al. recently identified the W168A mutant of Neurospora crassa nitrilase and observed significant increase in amide generation and decrease of $e e$ value for the products [141].

\section{Biotechnological potential of nitrilase}

Biocatalysis has long been seen by biochemists and microbiologists as an area with greater potential for chemical synthesis over conventional chemical processes [9]. A considerable amount of studies on nitrile biotransformation were carried out over the last few decades. Among them, nitrilase was proven a valuable candidate, and microbial cells were considered a potential producer for their scientific and industrial aspects. Moreover, microbial cells harboring nitrilase as a factory can be used to hydrolyze nitrile compounds into carboxylic acids and their derivatives. In this area, one of the most inspiring stories of success is the biosynthesis of acrylamide using NHase on a commercial scale, with an annual production exceeding 100,000 tons. Some nitrilases have also been successfully applied to practical production in food industries, chemical manufacturing, pharmaceutical processes, wastewater treatment and textile industries. 


\section{Application in carboxylic acid production Nicotinic acid}

Nicotinic acid, also known as niacin or vitamin B3, is often used in the production of feedstuff additives and pharmaceutical intermediates. The conventional method for preparing nicotinic acid was established over 100 years ago through oxidizing nicotine with potassium dichromate [142]. To date, the microbial transformation of 3-cyanopyridine was attempted to synthesize nicotinic acid (Figure 4A). Mathew et al. reported the use of free cells of $R$. rhodochrous $\mathrm{Jl}$ to directly catalyze of 3cyanopyridine to nicotinic acid, and the highest yield achieved was $172 \mathrm{~g} \cdot \mathrm{L}^{-1}$ nicotinic acid with $100 \%$ conversion rate of 3-cyanopyridine [33]. Alginate-immobilized B. pallidus Dac521 cells were used to continuously hydrolyze 3-cyanopyridine to nicotinic acid, and the conversion efficiency of about $104 \mathrm{mg}$ (substrate).g (cells) $)^{-1} \cdot \mathrm{h}^{-1}$ and $208 \mathrm{mg}$ (substrate).g (cells) $)^{-1} \cdot \mathrm{h}^{-1}$ was observed at $50^{\circ} \mathrm{C}$ and $60^{\circ} \mathrm{C}$, respectively, in the initial 10 $\mathrm{h}$ [121]. Fed-batch reaction was employed by Sharma et al. to prepare nicotinic acid through the $N$. globerula NHB-2 nitrilase, and the productivity of $3.21 \mathrm{mg}$ (nicotinic acid).mg (cells) ${ }^{-1} \cdot \mathrm{h}^{-1}$ was recorded in their study [143]. Prasad and co-workers revealed that the propionitrile-induced nitrilase of Rhodococcus sp. NDB 1165 can efficiently synthesize nicotinic acid at the rate of $8.95 \mathrm{mg}$ (product).mg (cells) ${ }^{-1} \cdot \mathrm{h}^{-1}$, and the highest yield achieved reached $196.8 \mathrm{~g} \cdot \mathrm{L}^{-1}$ nicotinic acid [49]. Lonza, the world's largest manufacturer of nicotinates, made an investment in China to produce nicotinic acid in a commercial scale $[23,144]$.

\section{(R)-(-)-mandelic acid}

$(R)-(-)$-mandelic acid is an important chiral building block, broadly used as optical resolving agents and intermediates for the production of various pharmaceutical

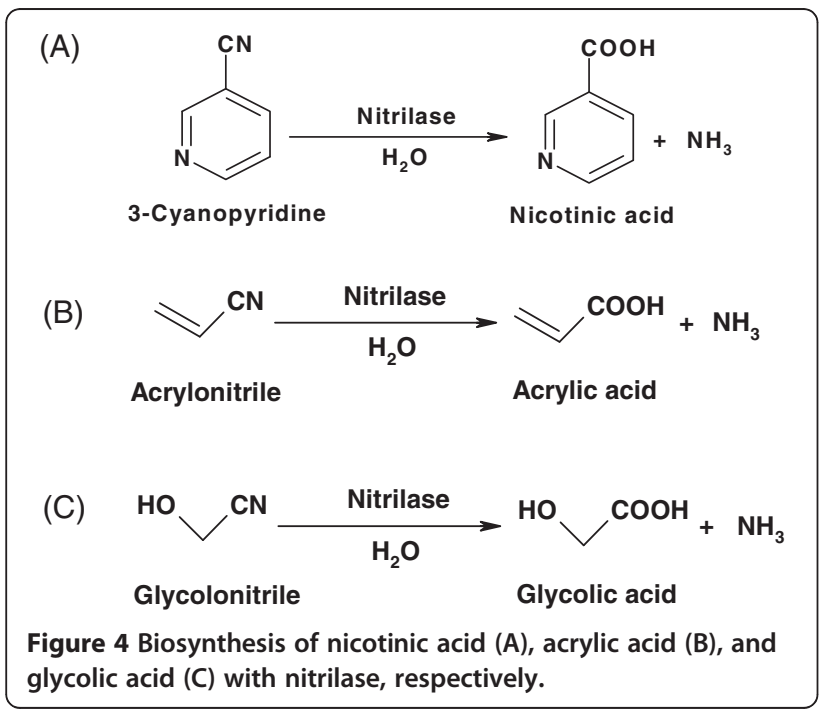

and agricultural products $[145,146] .(R)-(-)$-mandelic acid production can be performed using physicochemical methods and biocatalytic routes: the latter usually use $(R, S)$-mandelonitrile as substrate. In recent few years, the enantioselective biocatalytic routes for the production of $(R)-(-)$-mandelic acid with nitrilase from $(R, S)$-mandelonitrile were widely investigated by several groups, such as the Xu's and the Zheng's in China. This hydrolysis reaction by nitrilase generally proceeded to generate $(S)-(+)$-mandelonitrile and $(R)-(-)$-mandelic acid, whereas the residual $(S)-(+)$-mandelonitrile in the reaction mixture was spontaneously racemized due to the chemical equilibrium and used as substrate over again, as shown in Figure 5 [60]. As illustrated by the Xu's group, the recombinant Alcaligenes sp. nitrilase overexpressed in $E$. coli displayed an excellent specific activity of $7000 \mathrm{U} \cdot \mathrm{L}^{-1}$ toward $(R, S)$-mandelonitrile, and $520 \mathrm{mM}(R)-(-)$-mandelic acid was produced after $17.5 \mathrm{~h}$ of conversion with $600 \mathrm{mM}(R, S)$-mandelonitrile in a fed-batch reaction, in which the volumetric productivity and catalyst productivity reached up to $4.5 \mathrm{~g}$ (product) $\cdot \mathrm{L}^{-1} \cdot \mathrm{h}^{-1}$ and $0.79 \mathrm{~g}$ (product).g (cells) ${ }^{-1}$, respectively, with ee value of $99 \%$ [122]. These authors recently employed the toluene-water biphasic system to relieve substrate inhibition [147]. Finally, the average productivity of $352.6 \mathrm{~g}$ (product) $\cdot \mathrm{L}^{-1} \cdot \mathrm{d}^{-1}$ was achieved, and $110.7 \mathrm{~g}$ $(R)-(-)$-mandelic acid in $98.0 \%$ ee along with the catalyst productivity of $13.8 \mathrm{~g}$ (product).g (cells) ${ }^{-1}$ can be obtained when immobilized cells were repeatedly used for five batches in a $2-\mathrm{L}$ stirred reactor. Moreover, the mutant of $A$. faecalis obtained through ultraviolet irradiation and $\mathrm{N}^{+}$ion beam implantation technique by Zheng's group showed considerable potential in $(R)$ $(-)$-mandelic acid production, and its highest production rate reached $9.3 \mathrm{mM}$ (product).g (cells) ${ }^{-1} \cdot \mathrm{h}^{-1}$ with $93 \%$ yield and $e e$ value of more than 99\% [60]. Meanwhile, Saccharomyces cerevisiae FD11b was used by Xiao et al. to asymmetrically reduce the phenylglyoxylic acid to $(R)$ $(-)$-mandelic acid where the maximal production rate reached $0.353 \mathrm{mM}$ (product).g (cells) ${ }^{-1} \cdot \mathrm{h}^{-1}$, and the highest product concentration achieved about $120 \mathrm{mM}$ with an ee value of 97.1\% [148]. BASF in Germany and Mitsubishi Rayon in Japan are currently producing $(R)$ $(-)$-mandelic acid from $(R, S)$-mandelonitrile with at least several tons per year $[9,24,25,146]$.

\section{Acrylic acid}

Acrylic acid, also known as 2-propenoic acid, is a principal commodity chemical with an estimated annual output of 4.2 million metric tons [149]. Acrylic acid and its derivatives are widely used in surface coatings, textiles, adhesives, paper treatment, polymeric flocculants, dispersants, and so on [150]. Traditionally, commercial acrylic acid was produced from petrochemical industry using the two- 


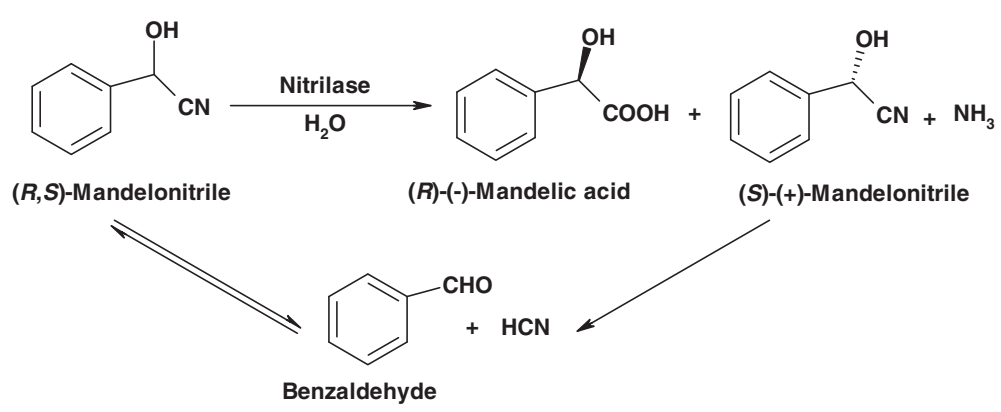

Figure 5 Biosynthesis of $(R)-(-)$-mandelic acid from $(R, S)$-mandelonitrile with nitrilase.

step gas-phase oxidation of propylene, in which several of the by-products, such as acrolein and large quantities of inorganic wastes, were unexpectedly generated [57]. Furthermore, acrylic acid may be prepared through fermentative production with sugars as a raw material [149]. The enzymatic hydrolysis of acrylonitrile using nitrilase is currently considered an attractive alternative for the synthesis of acrylic acid (Figure 4B). Very recently, a novel acrylonitrile-degrading $A$. nitroguajacolicus was isolated and characterized [57], and its enzymatic properties confirmed its application potential in acrylic acid production (specific activity of 202.24 U.g (cells) ${ }^{-1}$, halflife of $129.8 \mathrm{~h}$ at $40^{\circ} \mathrm{C}$ ). Zabaznaya et al. adopted a bacterial strain of Alcaligenes sp. for transforming acrylonitrile, and finally $115 \mathrm{~g} \cdot \mathrm{L}^{-1}$ acrylic acid was obtained over a $9 \mathrm{~h}$ reaction [151]. Moreover, the $R$. rhodochrous J1 nitrilase induced by $\varepsilon$-caprolactam was extremely specific toward acrylonitrile [152]. The highest accumulation of $390 \mathrm{~g} \cdot \mathrm{L}^{-1}$ acrylic acid was attained through transformation reaction mediated by this nitrilase. A mutant strain of $R$. rhodochrous tg1-A6, which was obtained after treatment through UV light combined with lithium chlorinate, was used to synthesize acrylic acid [153]. The results demonstrated that a final concentration of $414.5 \mathrm{~g} \cdot \mathrm{L}^{-1}$ acrylic acid was accumulated during a $10 \mathrm{~h}$ continuous catalytic reaction.

\section{Glycolic acid}

In recent years, $\alpha$-hydroxycarboxylic acids have become significant because of their important medical and pharmaceutical applications. These acids are broadly used in household cleaners, industrial and electronic elements, automotive oil additives, oil and water well flow enhancers, $\mathrm{pH}$ controlling, cosmetics, and many others [154]. Glycolic acid, the simplest kind of $\alpha$-hydroxycarboxylic acid, has been a subject of several studies due to its large demand and wide application. Majority of the commercially available glycolic acid are currently produced using high-pressure and high-temperature reaction of formaldehyde and carbon monoxide under acid catalysis [155]. Recently, several studies focused on the enzymatic transformation of glycolonitrile to glycolic acid (Figure 4C) [105,107,134,155]. The GA/PEI crosslinked carrageenan immobilized cells of Alcaligenes sp. were applied in glycolonitrile conversion [105]. A volumetric productivity of $18.0 \mathrm{~g}$ (product) $\cdot \mathrm{L}^{-1} \cdot \mathrm{h}^{-1}$ and total productivity of $1,042.2 \mathrm{~g}$ (product).g (cells) ${ }^{-1}$ were achieved after 29 cycles. The nitrilase from A. facilis $72 \mathrm{~W}$ was overexpressed and protein engineered to improve the catalytic efficiency for glycolonitrile [134]. An F168V mutant demonstrated the best performance, with a productivity of $1,010 \mathrm{~g}$ (product).g (cells) ${ }^{-1}$ after 55 recycle reactions.

\section{Bioremediation and biodegradation potential}

Nitriles can be degraded in the environmental contaminants by enzymatic reaction. This degradation is of great significance because most nitrile compounds are highly toxic, carcinogenic, and mutagenic in nature, which are considered harmful to human beings, animals, and plants [98]. These compounds typically included acetonitrile, acrylonitrile, succinonitrile, benzonitrile, dichlobenil, bromoxynil, and ioxynil, which are often used in industry and agriculture for pharmaceuticals, plastics, synthetic rubbers, herbicides, and pesticides $[13,98]$. The bioremediation potential of nitrilase has been illustrated in detail to degrade the compounds into harmless intermediates or, ultimately, carbon dioxide, as well as $\mathrm{H}_{2} \mathrm{O}$. Several microorganisms are involved in the degradation of nitriles in literature $[13,16,17,156]$. Zhou et al. reported that sodium alginate immobilized the microbial cells, which were isolated from acrylic fiber production wastewater and can degrade more than $80 \%$ of succinonitrile at the initial concentration of even $5,000 \mathrm{mg} \cdot \mathrm{L}^{-1}$ after $24 \mathrm{~h}$ [156]. K. pneumoniae subsp. ozaenae was obtained by enrichment strategies with the herbicide bromoxynil as a nitrogen source, and was found capable of rapid conversion of $0.05 \%$ bromoxynil to 3,5 dibromo-4-hydroxybenzoic acid [157]. The nitrilase gene was cloned and expressed in E. coli, and the recombinant nitrilase was highly specific for bromoxynil with $V_{\max }$ of $15 \mu \mathrm{M}\left(\mathrm{NH}_{3}\right) \cdot \mathrm{mg}$ (protein $)^{-1} \cdot \mathrm{min}^{-1}$ [41]. The soil 
actinobacteria $R$. rhodochrous PA-34, Rhodococcus sp. NDB 1165, and N. globerula NHB-2 exhibited excellent specific activities towards benzonitrile [16]. These bacteria can hydrolyze chloroxynil and bromoxynil completely, whereas $60 \%$ of ioxynil with $0.5 \mathrm{mM}$ substrate concentration is hydrolyzed into corresponding acids after $20 \mathrm{~h}$ incubation. Other strains are also reported to have significant nitrilase activity for nitrile bioremediation, such as the genus of Alcaligenes, Bacillus, Stemphylium, Fusarium, Pseudomonas, and Arthrobacter $[17,158]$.

\section{Surface modification of polymers}

Approximately 2.73 million tons of polyacrylonitrile (PAN) are produced worldwide by polymerization of acrylonitrile per year [159]. Most of these PAN were used as fibers in textile processing. Conventional chemical methods have difficulty to improve the quality and the processing properties of fibers. The treatment using strong acids or alkali, high reaction temperatures, aggressive chemicals, and high concentrations of dimethyl sulfoxide would lead to irreversible yellowing and unwanted changes in the macroscopic behavior of the fabrics [160]. Therefore, surface modification through selective enzymatic hydrolysis is a more promising alternative to specifically modify the PAN surface to make fibers more hydrophilic and enhance the dye uptake. NHases are regularly adopted to selectively modify the PAN surface groups, such as those from B. imperiale CBS 49874 and Corynebacterium nitrilophilus ATCC 21419 [161]. Information on the surface modification mediated by nitrilase is rare. Matamá et al. described the first case of direct enzymatic modification of $-\mathrm{CN}$ groups into $-\mathrm{COOH}$ on fibres using a commercial nitrilase [162]. Their experimental results showed that the staining level of samples treated with nitrilase increased by $156 \%$ compared with the control, and 199\% of the increase can be observed by the addition of $1 \mathrm{M}$ sorbitol and $4 \% \mathrm{~N}, \mathrm{~N}$-dimethylacetamide. Almost simultaneously, Micrococcus luteus BST20 was isolated by FischerColbrie et al. with PAN polymers as sole carbon source [159]. The staining depth of the PAN fabrics was substantially improved when treated by this catalyst. The nitrilase from E. coli BL21 (DE3)/pET-Nit can also effectively modify the surface of PAN fibers and membrane [163]. The hydrophilicity and fabric-dyeing efficiency of these fibers were obviously increased and yet the strength of treated fiber decreased by only $1.17 \%$.

\section{Major challenges faced by researchers}

Nitrilase-mediated biocatalysis has undergone fast development, and it is expected that some limitations would be overcome in the future. The biocatalytic process develops biocatalysts with appropriate activities and stability as a "top priority". Therefore, the present and future research efforts would be focused on improving enzyme properties, such as substrate spectrum, stability, specificity, and function in non-classical environments [9].

The specific activity of most nitrilases is lower than that of commercial application. An extremely small proportion of native strains and protein sequences is presently available to the scientific community [164]. The screening and discovery of novel nitrilase-producing strains or new nitrile converting enzymes with greater potential is still currently conducted.

Second, the substrate spectrum of nitrilase needed to be widened. In the long term, narrow substrate spectrum is a limiting factor in the development of general purpose catalysts [6]. Nitrilases that can degrade a wide range of nitrile substrates to various carboxylic acids, would become a research interest of chemists and biotechnologists.

Third, operational stability should be improved from the industrial application perspective. The operational stability of nitrilase can be increased through the isolation of stable wild type strains using certain screening methods and then reengineering the target strain toward better stability through gene modification [165].

Finally, biocatalysis reaction in organic solvents would become a hot topic in this area. Nitrile compounds are poorly soluble in water or buffer solutions, thus, organic solvents can increase the solubility of substrates, thereby prompting catalytic efficiency. Nevertheless most organic solvents may affect the protein structure or destroy the enzyme activity. Therefore, enzymatic catalysis in organic solvents requires further investigations.

\section{Conclusions and future prospects}

Nitrilase-producing organisms are useful cell factories for the production of commercially important carboxylic acids. The waste treatment and textile industry also have drawn benefits from nitrilase due to its bioremediation and surface modification functions. The microbiological, enzymological, and molecular biological aspects of nitrilase were investigated by a large number of scholars and have made its industrial application an attractive alternative. Overcoming the disadvantages of nitrilase would further widen its application in organic synthesis. Meanwhile, new techniques have been introduced and developed in the recent years; thus researchers have gained greater opportunities in promoting nitrilase as a more promising biocatalyst. Molecular biology technique, genetic engineering, immobilization, enzyme engineering, enzyme crystallography, and process engineering would receive increasing attention for the improvement of the catalytic properties of nitrilase. The research for extreme microorganisms including those of thermophile, alkali/ acid resistance, and substrate tolerance would extend 
the application scope of nitrilase $[21,166]$. High throughput screening is widely applied in the selection of improved biocatalysts. Some novel strategies, including rational protein design, as well as the combination of the rational design and directed evolution [10] are worthy of reconsideration for a versatile and powerful biocatalyst with wide substrate spectrum, efficient catalytic activity, and excellent operational stability. Inevitably, broader application of nitrilase is expected in the near future.

\begin{abstract}
Abbreviations
NHase: Nitrile hydratase; Bromoxynil: 3,5-dibromo-4-hydroxybenzonitrile; Ioxynil: 3,5-diiodo-4-hydroxybenzonitrile; AtNIT: Arabidopsis thaliana nitrilase: PAN: Polyacrylonitrile; IAN: Indole-3-acetonitrile; IAA: Indole-3-acetic acid; NMR: Nuclear magnetic resonance; CD: Circular dichroism; EDTA: Ethylene diamine tetra acetic acid; EP- PCR: Error-prone polymerase chain reaction.
\end{abstract}

\section{Competing interests}

The authors declare that they have no competing interests.

\section{Authors' contributions}

All authors defined the topic of the review and wrote, read and approved the manuscript.

\section{Acknowledgements}

The authors would sincerely like to thank Prof. Zhi-Song Shen for his substantial support for this project. We also wish to thank Muhammad Masfiqur Rahman for critically reading the manuscript. This work was financially supported by the National High Technology Research and Development Program of China (No. 2011AA02A211), the Fundamental Research Funds for the Central Universities (No. JUSRP111A51), and Research and Innovation Project for College Graduates of Jiangsu Province (No. CXLX12_0731).

\section{Author details}

'The Key Laboratory of Industrial Biotechnology, Ministry of Education, Jiangnan University, Wuxi, People's Republic of China. 'Laboratory of Pharmaceutical Engineering, School of Medicine and Pharmaceutics, Jiangnan University, Wuxi 214122, People's Republic of China. ${ }^{3}$ Laboratory of Bioactive Products Processing Engineering, School of Medicine and

Pharmaceutics, Jiangnan University, Wuxi 214122, People's Republic of China.

Received: 24 August 2012 Accepted: 23 October 2012

Published: 30 October 2012

\section{References}

1. Noyori R: Synthesizing our future. Nat Chem 2009, 1:5-6.

2. Clark JH: Chemistry goes green. Nat Chem 2009, 1:12-13.

3. Wohlgemuth R: Biocatalysis - key to sustainable industrial chemistry. Curr Opin Biotech 2010, 21:713-724.

4. Sheldon RA: E factors, green chemistry and catalysis: an odyssey. Chem Commun 2008, 29:3352-3365.

5. Tao J, Xu J-H: Biocatalysis in development of green pharmaceutical processes. Curr Opin Chem Biol 2009, 13:43-50.

6. Koeller KM, Wong C-H: Enzymes for chemical synthesis. Nature 2001, 409:232-240.

7. Ran N, Zhao L, Chen Z, Tao J: Recent applications of biocatalysis in developing green chemistry for chemical synthesis at the industrial scale. Green Chem 2008, 10:361-372.

8. Schulze B, Wubbolts MG: Biocatalysis for industrial production of fine chemicals. Curr Opin Biotechnol 1999, 10:609-615.

9. Schmid A, Dordick JS, Hauer B, Kiener A, Wubbolts M, Witholt B: Industrial biocatalysis today and tomorrow. Nature 2001, 409:258-266.

10. Savile CK, Janey JM, Mundorff EC, Moore JC, Tam S, Jarvis WR, Colbeck JC, Krebber A, Fleitz FJ, Brands J, Devine PN, Huisman GW, Hughes GJ: Biocatalytic asymmetric synthesis of chiral amines from ketones applied to sitagliptin manufacture. Science 2010, 329:305-309.

11. Schoemaker HE, Mink D, Wubbolts MG: Dispelling the myths-biocatalysis in industrial synthesis. Science 2003, 299:1694-1697.
12. Sanderson K: Chemistry: Enzyme expertise. Nature 2011, 471:397-398.

13. Banerjee A, Sharma R, Banerjee UC: The nitrile-degrading enzymes: current status and future prospects. Appl Microbiol Biotechnol 2002, 60:33-44.

14. Rey P, Rossi J-C, Taillades J, Gros G, Nore O: Hydrolysis of nitriles using an immobilized nitrilase: Applications to the synthesis of methionine hydroxy analogue derivatives. J Agric Food Chem 2004, 52:8155-8162.

15. Mylerova V, Martinkova L: Synthetic applications of nitrile-converting enzymes. Curr Org Chem 2003, 7:1279-1295.

16. Veselá A, Franc M, Pelantová H, Kubáč D, Vejvoda V, Šulc M, Bhalla T, Macková M, Lovecká P, Janů P, Demnerová K, Martínková L: Hydrolysis of benzonitrile herbicides by soil actinobacteria and metabolite toxicity. Biodegradation 2010, 21:761-770.

17. Martínková L, Uhnáková B, Pátek $M$, Nešvera J, Křen V: Biodegradation potential of the genus Rhodococcus. Environ Int 2009, 35:162-177.

18. Zhou ZM, Hashimoto Y, Kobayashi M: Nitrile degradation by Rhodococcus: Useful microbial metabolism for industrial productions. Actinomycetologica 2005, 19:18-26.

19. Thimann KV, Mahadevan S: Nitrilase. I. Occurrence, preparation, and general properties of the enzyme. Arch Biochem Biophys 1964, 105:133-141.

20. Martínková L, Vejvoda V, Kaplan O, Kubáč D, Malandr A, Cantarella M, Bezouška K, Křen V: Fungal nitrilases as biocatalysts: Recent developments. Biotechnol Adv 2009, 27:661-670.

21. Rustler S, Stolz A: Isolation and characterization of a nitrile hydrolysing acidotolerant black yeast - Exophiala oligosperma R1. Appl Microbiol Biotechnol 2007, 75:899-908.

22. Piotrowski M: Primary or secondary? Versatile nitrilases in plant metabolism. Phytochemistry 2008, 69:2655-2667.

23. Shaw NM, Robins KT, Kiener A: Lonza: 20 years of biotransformations. Adv Synth Catal 2003, 345:425-435.

24. Brady D, Beeton A, Zeevaart J, Kgaje C, Rantwijk F, Sheldon RA: Characterisation of nitrilase and nitrile hydratase biocatalytic systems. Appl Microbiol Biotechnol 2004, 64:76-85.

25. Kaul P, Banerjee A, Banerjee UC: Nitrile hydrolases. In Industrial Enzymes. Edited by Polaina J, MacCabe AP. India: Springer; 2007:531-547.

26. Kobayashi M, Shimizu S: Versatile nitrilases: Nitrile - hydrolyzing enzymes. FEMS Microbiol Lett 1994, 120:217-224.

27. Robinson WG, Hook RH: Ricinine nitrilase: I. Reaction product and substrate specificity. J Biol Chem 1964, 239:4257-4262.

28. Hook RH, Robinson WG: Ricinine nitrilase: II. Purification and properties. J Biol Chem 1964, 239:4263-4267.

29. Harper DB: Microbial metabolism of aromatic nitriles: enzymology of C-N cleavage by Nocardia sp.(Rhodochrous group) N.C.I.B. 11216. Biochem J 1977, 165:309-319.

30. Gradley ML, Deverson CJF, Knowles CJ: Asymmetric hydrolysis of R-(-), S (+)-2-methylbutyronitrile by Rhodococcus rhodochrous NCIMB 11216. Arch Microbiol 1994, 161:246-251.

31. Yanase $H$, Sakai T, Tonomura K: Purification, crystallization and some properties of $\beta$-cyano-L-alanine-degrading enzyme in Pseudomonas sp. 13. Agric Biol Chem 1983, 47:473-482.

32. Macadam AM, Knowles CJ: The stereospecific bioconversion of a-aminopropionitrile to L-alanine by an immobilised bacterium isolated from soil. Biotechnol Lett 1985, 7:865-870.

33. Mathew CD, Nagasawa T, Kobayashi M, Yamada H: Nitrilase-catalyzed production of nicotinic acid from 3-cyanopyridine in Rhodococcus rhodochrous J1. Appl Environ Microbiol 1988, 54:1030-1032.

34. Kobayashi M, Nagasawa T, Yamada H: Nitrilase of Rhodococcus rhodochrous J1: Purification and characterization. Eur J Biochem 1989, 182:349-356.

35. Lévy-Schil S, Soubrier F, Crutz-Le Coq A-M, Faucher D, Crouzet J, Pétré D: Aliphatic nitrilase from a soil-isolated Comamonas testosteroni sp.: gene cloning and overexpression, purification and primary structure. Gene 1995, 161:15-20.

36. Nagasawa T, Mauger J, Yamada H: A novel nitrilase, arylacetonitrilase, of Alcaligenes faecalis JM3: Purification and characterization. Eur J Biochem 1990, 194:765-772.

37. Yamamoto K, Komatsu K-i: Purification and characterization of nitrilase responsible for the enantioselective hydrolysis from Acinetobacter sp. AK 226. Agric Biol Chem 1991, 55:1459-1466. 
38. Yamamoto K, Fujimatsu I, Komatsu K-I: Purification and characterization of the nitrilase from Alcaligenes faecalis ATCC 8750 responsible for enantioselective hydrolysis of mandelonitrile. J Ferment Bioeng 1992 73:425-430.

39. Bhalla TC, Miura A, Wakamoto A, Ohba Y, Furuhashi K: Asymmetric hydrolysis of a-aminonitriles to optically active amino acids by a nitrilase of Rhodococcus rhodochrous PA-34. Appl Microbiol Biotechnol 1992, 37:184-190.

40. Kobayashi M, Yanaka N, Nagasawa T, Yamada H: Purification and characterization of a novel nitrilase of Rhodococcus rhodochrous $\mathrm{K} 22$ that acts on aliphatic nitriles. J Bacteriol 1990, 172:4807-4815

41. Stalker DM, Malyj LD, McBride KE: Purification and properties of a nitrilase specific for the herbicide bromoxynil and corresponding nucleotide sequence analysis of the bxn gene. J Biol Chem 1988, 263:6310-6314.

42. Almatawah QA, Cramp R, Cowan DA: Characterization of an inducible nitrilase from a thermophilic bacillus. Extremophiles 1999, 3:283-291.

43. Hoyle AJ, Bunch AW, Knowles CJ: The nitrilases of Rhodococcus rhodochrous NCIMB 11216. Enzyme Microb Technol 1998, 23:475-482.

44. Layh N, Parratt J, Willetts A: Characterization and partial purification of an enantioselective arylacetonitrilase from Pseudomonas fluorescens DSM 7155. J Mol Catal B: Enzym 1998, 5:467-474.

45. Bhalla TC, Kumar H: Nocardia globerula NHB-2: a versatile nitrile-degrading organism. Can J Microbiol 2005, 51:705-708.

46. Banerjee A, Kaul P, Banerjee U: Purification and characterization of an enantioselective arylacetonitrilase from Pseudomonas putida. Arch Microbiol 2006, 184:407-418.

47. Mueller P, Egorova K, Vorgias CE, Boutou E, Trauthwein H, Verseck S, Antranikian G: Cloning, overexpression, and characterization of a thermoactive nitrilase from the hyperthermophilic archaeon Pyrococcus abyssi. Protein Expr Purif 2006, 47:672-681.

48. Chauhan S, Wu S, Blumerman S, Fallon RD, Gavagan JE, DiCosimo R, Payne MS: Purification, cloning, sequencing and over-expression in Escherichia coli of a regioselective aliphatic nitrilase from Acidovorax facilis $72 \mathrm{~W}$. Appl Microbiol Biotechnol 2003, 61:118-122.

49. Prasad S, Misra A, Jangir $V$, Awasthi A, Raj J, Bhalla T: A propionitrileinduced nitrilase of Rhodococcus sp. NDB 1165 and its application in nicotinic acid synthesis. World J Microbiol Biotechnol 2007, 23:345-353.

50. Zhu D, Mukherjee C, Biehl ER, Hua L: Discovery of a mandelonitrile hydrolase from Bradyrhizobium japonicum USDA110 by rational genome mining. J Biotechnol 2007, 129:645-650.

51. Alonso FOM, Oestreicher EG, Antunes OAC: Production of enantiomerically pure D-phenylglycine using Pseudomonas aeruginosa 10145 as biocatalyst. Braz J Chem Eng 2008, 25:1-8.

52. Chmura A, Shapovalova AA, van Pelt S, van Rantwijk F, Tourova TP, Muyzer G, Sorokin DY: Utilization of arylaliphatic nitriles by haloalkaliphilic Halomonas nitrilicus sp. nov. isolated from soda soils. Appl Microbiol Biotechnol 2008, 81:371-378.

53. Zheng YG, Chen J, Liu ZQ, Wu MH, Xing LY, Shen YC: Isolation, identification and characterization of Bacillus subtilis ZJB-063, a versatile nitrile-converting bacterium. Appl Microbiol Biotechnol 2008, 77:985-993.

54. Zhang Z-J, Xu J-H, He Y-C, Ouyang L-M, Liu Y-Y: Cloning and biochemical properties of a highly thermostable and enantioselective nitrilase from Alcaligenes sp. ECU0401 and its potential for (R)-(-)-mandelic acid production. Bioproc Biosyst Eng 2011, 34:315-322.

55. Kim J-S, Tiwari M, Moon H-J, Jeya M, Ramu T, Oh D-K, Kim I-W, Lee J-K Identification and characterization of a novel nitrilase from Pseudomonas fluorescens Pf-5. Appl Microbiol Biotechnol 2009, 83:273-283.

56. Nigam VK, Khandelwal AK, Gothwal RK, Mohan MK, Choudhury B, Vidyarthi AS, Ghosh P: Nitrilase-catalysed conversion of acrylonitrile by free and immobilized cells of Streptomyces sp. J Biosci 2009, 34:21-26.

57. Shen $M$, Zheng $Y-G$, Shen $Y-C$ : Isolation and characterization of a novel Arthrobacter nitroguajacolicus ZJUTB06-99, capable of converting acrylonitrile to acrylic acid. Process Biochem 2009, 44:781-785.

58. Dong H-P, Liu Z-Q, Zheng Y-G, Shen Y-C: Novel biosynthesis of ( $R$ )-ethyl-3hydroxyglutarate with $(R)$-enantioselective hydrolysis of racemic ethyl 4-cyano-3-hydroxybutyate by Rhodococcus erythropolis. Appl Microbiol Biotechnol 2010, 87:1335-1345.

59. Williamson DS, Dent KC, Weber BW, Varsani A, Frederick J, Thuku RN, Cameron RA, van Heerden JH, Cowan DA, Sewell BT: Structural and biochemical characterization of a nitrilase from the thermophilic bacterium, Geobacillus pallidus RAPc8. Appl Microbiol Biotechnol 2010, 88:143-153.

60. Xue $Y-P$, Xu S-Z, Liu Z-Q, Zheng Y-G, Shen Y-C: Enantioselective biocatalytic hydrolysis of $(R, S)$-mandelonitrile for production of (R)-(-)-mandelic acid by a newly isolated mutant strain. J Ind Microbiol Biotechnol 2011, 38:337-345.

61. Nageshwar MD, Sheelu G, Shambhu RR, Muluka H, Mehdi N, Malik MS, Kamal A: Optimization of nitrilase production from Alcaligenes faecalis MTCC 10757 (IICT-A3): effect of inducers on substrate specificity. Bioproc Biosyst Eng 2011, 34:515-523.

62. Hsu JC, Camper ND: Degradation of ioxynil by a soil fungus, Fusarium solani. Soil Biol Biochem 1979, 11:19-22.

63. Harper DB: Fungal degradation of aromatic nitriles. Enzymology of C-N cleavage by Fusarium solani. Biochem J 1977, 167:685-692.

64. Goldlust A, Bohak Z: Induction, purification, and characterization of the nitrilase of Fusarium oxysporum $\mathrm{f} \mathrm{sp}$. melonis. Biotechnol Appl Biochem 1989, 11:581-601.

65. Winkler M, Kaplan O, Vejvoda V, Klempier N, Martínková L: Biocatalytic application of nitrilases from Fusarium solani $\mathrm{O} 1$ and Aspergillus niger K10. J Mol Catal B: Enzym 2009, 59:243-247.

66. Kaplan O, Vejvoda V, Plíhal O, Pompach P, Kavan D, Bojarová P, Bezouška K Macková M, Cantarella M, Jirků V, Křen V, Martínková L: Purification and characterization of a nitrilase from Aspergillus niger K10. Appl Microbiol Biotechnol 2006, 73:567-575.

67. Vejvoda V, Kaplan O, Bezouska K, Pompach P, Sulc M, Cantarella M, Benada O, Uhnáková B, Rinágelová A, Lutz-Wahl S, Fischer L, Kren V, Martínková L: Purification and characterization of a nitrilase from Fusarium solani 01. J Mol Catal B: Enzym 2008, 50:99-106.

68. Kaplan O, Bezouska K, Plihal O, Ettrich R, Kulik N, Vanek O, Kavan D, Benada O, Malandra A, Sveda O, Vesela A, Rinagelova A, Slamova K, Cantarella M, Felsberg J, Duskova J, Dohnalek J, Kotik M, Kren V, Martinkova L: Heterologous expression, purification and characterization of nitrilase from Aspergillus niger K10. BMC Biotechnol 2011, 11:1-15.

69. Vejvoda V, Kubác D, Davidová A, Kaplan O, Sulc M, Sveda O, Chaloupková R, Martínková L: Purification and characterization of nitrilase from Fusarium solani IMI196840. Process Biochem 2010, 45:1115-1120.

70. Choi SY, Goo YM: Hydrolysis of the nitrile group in aaminophenylacetonitrile by nitrilase; Development of a new biotechnology for stereospecific production of S-a-phenylglycine. Arch Pharm Res 1986, 9:45-47.

71. Bhalla TC, Sharma M, Sharma NN: Nitrile Metabolizing Yeasts. In Yeast Biotechnology: Diversity and Applications. Edited by Satyanarayana T, Kunze G. Netherlands: Springer; 2009:715-735.

72. Brewis EA, Walt JPVD, Prior BA: The utilization of aromatic, cylic and heterocyclic nitriles by yeasts. Syst Appl Microbiol 1995, 18:338-342.

73. Fukuda $Y$, Harada T, Izumi Y: Formation of L-a-hydroxy-acids from D, L-ahydroxynitriles by Torulopsis candida GN405. J Ferment Technol 1973, 51:393-397.

74. Rustler S, Chmura A, Sheldon RA, Stolz A: Characterisation of the substrate specificity of the nitrile hydrolyzing system of the acidotolerant black yeast Exophiala oligosperma R1. Stud Mycol 2008, 61:165-174.

75. Rezende RP, Teixeira Dias JC, Ferraz V, Linardi VR: Metabolism of benzonitrile by Cryptococcus sp. UFMG-Y28. J Basic Microbiol 2000, 40:389-392.

76. Rausch T, Hilgenberg W: Partial purification of nitrilase from Chinese cabbage. Phytochemistry 1980, 19:747-750.

77. Ishikawa T, Okazaki K, Kuroda H, Itoh K, Mitsui T, Hori H: Molecular cloning of Brassica rapa nitrilases and their expression during clubroot development. Mol Plant Pathol 2007, 8:623-637.

78. Agerbirk N, Warwick SI, Hansen PR, Olsen CE: Sinapis phylogeny and evolution of glucosinolates and specific nitrile degrading enzymes. Phytochemistry 2008, 69:2937-2949.

79. Piotrowski M, Schönfelder S, Weiler EW: The Arabidopsis thaliana isogene NIT4 and its orthologs in tobacco encode $\beta$-Cyano-L-alanine hydratase/nitrilase. J Biol Chem 2001, 276:2616-2621.

80. Janowitz T, Trompetter I, Piotrowski M: Evolution of nitrilases in glucosinolate-containing plants. Phytochemistry 2009, 70:1680-1686.

81. Vorwerk S, Biernacki S, Hillebrand H, Janzik I, Müller A, Weiler EW, Piotrowski M: Enzymatic characterization of the recombinant Arabidopsis thaliana nitrilase subfamily encoded by the NIT2/NIT1/NIT3-gene cluster. Planta 2001, 212:508-516 
82. Piotrowski M, Volmer J: Cyanide metabolism in higher plants: cyanoalanine hydratase is a NIT4 Homolog. Plant Mol Biol 2006, 61:111-122.

83. Jenrich R, Trompetter I, Bak S, Olsen CE, Møller BL, Piotrowski M: Evolution of heteromeric nitrilase complexes in Poaceae with new functions in nitrile metabolism. Proc Natl Acad Sci USA 2007, 104:18848-18853.

84. Sánchez-Pérez R, Jørgensen K, Olsen CE, Dicenta F, Møller BL: Bitterness in almonds. Plant Physiol 2008, 146:1040-1052

85. Yamada $H$, Kobayashi M: Nitrile hydratase and its application to industrial production of acrylamide. Biosci Biotechnol Biochem 1996, 60:1391-1400.

86. Gong J-S, Lu Z-M, Shi J-S, Dou W-F, Xu H-Y, Zhou Z-M, Xu Z-H: Isolation, identification, and culture optimization of a novel glycinonitrile hydrolyzing fungus-Fusarium oxysporum H3. Appl Biochem Biotechnol 2011, 165:963-977.

87. Yazbeck DR, Durao PJ, Xie Z, Tao J: A metal ion-based method for the screening of nitrilases. J Mol Catal B: Enzym 2006, 39:156-159.

88. Kruse JM, Mellon MG: Colorimetric determination of ammonia and cyanate. Anal Chem 1953, 25:1188-1192.

89. Scheiner D: Determination of ammonia and Kjeldahl nitrogen by indophenol method. Water Res 1976, 10:31-36.

90. Van Sint Fiet S, van Beilen JB, Witholt B: Selection of biocatalysts for chemical synthesis. Proc Natl Acad Sci USA 2006, 103:1693-1698.

91. Santoshkumar M, Nayak A, Anjaneya O, Karegoudar T: A plate method for screening of bacteria capable of degrading aliphatic nitriles. J Ind Microbiol Biotechnol 2010, 37:111-115.

92. He Y-C, Ma C-L, Xu J-H, Zhou L: A high-throughput screening strategy for nitrile-hydrolyzing enzymes based on ferric hydroxamate spectrophotometry. App/ Microbiol Biotechnol 2011, 89:817-823.

93. Zhu Q, Fan A, Wang Y-S, Zhu X-Q, Wang Z, Wu M-H, Zheng Y-G: Novel sensitive high-throughput screening strategy for nitrilase-producing strains. Appl Environ Microbiol 2007, 73:6053-6057.

94. Banerjee A, Sharma R, Banerjee UC: A rapid and sensitive fluorometric assay method for the determination of nitrilase activity. Biotechnol Appl Biochem 2003, 37:289-293.

95. Pace HC, Hodawadekar SC, Draganescu A, Huang J, Bieganowski P, Pekarsky Y, Croce CM, Brenner C: Crystal structure of the worm NitFhit Rosetta Stone protein reveals a Nit tetramer binding two Fhit dimers. Curr Biol 2000, 10:907-917.

96. Thuku RN, Weber BW, Varsani A, Sewell BT: Post-translational cleavage of recombinantly expressed nitrilase from Rhodococcus rhodochrous $\mathrm{J1}$ yields a stable, active helical form. FEBS J 2007, 274:2099-2108.

97. Kiziak C, Klein J, Stolz A: Influence of different carboxy-terminal mutations on the substrate-, reaction- and enantiospecificity of the arylacetonitrilase from Pseudomonas fluorescens EBC191. Protein Eng Des Sel 2007, 20:385-396.

98. Chen J, Zheng R-C, Zheng Y-G, Shen Y-C: Microbial transformation of nitriles to high-value acids or amides. Adv Biochem Eng Biotechnol 2009, 113:33-77.

99. Brady D: Biocatalytic hydrolysis of nitriles. In Handbook of Green Chemistry. Edited by Crabtree RH. Weinheim: Wiley-VCH Verlag GmbH \& Co. KGaA; 2010:27-49.

100. Fernandes BCM, Mateo C, Kiziak C, Chmura A, Wacker J, van Rantwijk F, Stolz A, Sheldon RA: Nitrile hydratase activity of a recombinant nitrilase. Adv Synth Catal 2006, 348:2597-2603.

101. Stevenson DE, Feng FD R, Groleau D, Mihoc A, Storer AC: Mechanistic and structural studies on Rhodococcus ATCC 39484 nitrilase. Biotechnol Appl Biochem 1992, 15:283-302.

102. Nagasawa T, Wieser M, Nakamura T, Iwahara H, Yoshida T, Gekko K: Nitrilase of Rhodococcus rhodochrous J1. Conversion into the active form by subunit association. Eur J Biochem 2000, 267:138-144.

103. Mao X-B, Eksriwong T, Chauvatcharin S, Zhong J-J: Optimization of carbon source and carbon/nitrogen ratio for cordycepin production by submerged cultivation of medicinal mushroom Cordyceps militaris. Process Biochem 2005, 40:1667-1672.

104. Banerjee A, Kaul P, Banerjee U: Enhancing the catalytic potential of nitrilase from Pseudomonas putida for stereoselective nitrile hydrolysis. Appl Microbiol Biotechnol 2006, 72:77-87

105. He Y-C, Xu J-H, Su J-H, Zhou L: Bioproduction of glycolic acid from glycolonitrile with a new bacterial isolate of Alcaligenes sp. ECU0401. Appl Biochem Biotechnol 2009, 160:1428-1440.
106. Shen M, Liu Z-Q, Zheng Y-G, Shen Y-C: Enhancing endo-nitrilase production by a newly isolated Arthrobacter nitroguajacolicus ZJUTB06-99 through optimization of culture medium. Biotechnol Bioproc Eng 2009, 14:795-802.

107. Hu JG, Wang YJ, Zheng YG, Shen YC: Isolation of glycolonitrile-hydrolyzing microorganism based on colorimetric reaction. Enzyme Microb Technol 2007, 41:244-249.

108. Stalker DM, McBride KE: Cloning and expression in Escherichia coli of a Klebsiella ozaenae plasmid-borne gene encoding a nitrilase specific for the herbicide bromoxynil. J Bacteriol 1987, 169:955-960.

109. Babu V, Shilpi, Choudhury B: Nitrile-metabolizing potential of Amycolatopsis sp. IITR215. Process Biochem 2010, 45:866-873.

110. Nagasawa T, Nakamura T, Yamada H: $\varepsilon$-Caprolactam, a new powerful inducer for the formation of Rhodococcus rhodochrous $\mathrm{J} 1$ nitrilase. Arch Microbiol 1990, 155:13-17.

111. Vejvoda V, Kaplan O, Klozova J, Masák J, Cejková A, Jirků V, Stloukal R, Martínková L: Mild hydrolysis of nitriles by Fusarium solani strain 01. Folia Microbiol 2006, 51:251-256.

112. Prasad S, Bhalla TC: Nitrile hydratases (NHases): At the interface of academia and industry. Biotechnol Adv 2010, 28:725-741.

113. Nagasawa T, Kobayashi M, Yamada H: Optimum culture conditions for the production of benzonitrilase by Rhodococcus rhodochrous J1. Arch Microbiol 1988, 150:89-94.

114. Kaul P, Banerjee A, Mayilraj S, Banerjee UC: Screening for enantioselective nitrilases: kinetic resolution of racemic mandelonitrile to (R)-(-)-mandelic acid by new bacterial isolates. Tetrahedron Asymmetr 2004, 15:207-211.

115. Griengl H, Hickel AV, Johnson D, Schmidt M, Kratky C, Schwab H: Enzymatic cleavage and formation of cyanohydrins: a reaction of biological and synthetic relevance. Chem Commun 1997, 20:1933-1940.

116. Heinemann U, Engels D, Burger S, Kiziak C, Mattes R, Stolz A: Cloning of a nitrilase gene from the cyanobacterium Synechocystis sp. strain PCC6803 and heterologous expression and characterization of the encoded protein. Appl Environ Microbiol 2003, 69:4359-4366.

117. Layh N, Willetts A: Enzymatic nitrile hydrolysis in low water systems. Biotechnol Lett 1998, 20:329-331.

118. Bauer $M$, Griengl $H$, Steiner W: Parameters influencing stability and activity of a S-hydroxynitrile lyase from Hevea brasiliensis in two-phase systems. Enzyme Microb Technol 1999, 24:514-522.

119. Costes D, Rotčnkovs G, Wehtje E, Adlercreutz P: Stability and stabilization of hydroxynitrile lyase in organic solvents. Biocatal Biotransform 2001, 19:119-130.

120. Pollard DJ, Woodley JM: Biocatalysis for pharmaceutical intermediates: the future is now. Trends Biotechnol 2007, 25:66-73.

121. Almatawah QA, Cowan DA: Thermostable nitrilase catalysed production of nicotinic acid from 3-cyanopyridine. Enzyme Microb Technol 1999, 25:718-724.

122. Zhang Z-J, Xu J-H, He Y-C, Ouyang L-M, Liu Y-Y, Imanaka T: Efficient production of $(R)-(-)$-mandelic acid with highly substrate/product tolerant and enantioselective nitrilase of recombinant Alcaligenes sp. Process Biochem 2010, 45:887-891.

123. Harper DB: Characterization of a nitrilase from Nocardia sp. (Rhodochrous group) N.C.I.B. 11215, Using p-hydroxybenzonitrile as sole carbon source. Int J Biochem 1985, 17:677-683.

124. Reetz MT, Zonta A, Simpelkamp J: Effiziente heterogene biokatalysatoren durch den einschluß von lipasen in hydrophoben sol-gel-materialien. Angew Chem 1995, 107:373-376.

125. Velankar H, Clarke KG, Preez R, Cowan DA, Burton SG: Developments in nitrile and amide biotransformation processes. Trends Biotechnol 2010, 28:561-569.

126. Kaul P, Banerjee A, Banerjee UC: Stereoselective nitrile hydrolysis by immobilized whole-cell biocatalyst. Biomacromolecules 2006, 7:1536-1541.

127. Dias J, Rezende R, Linard V: Bioconversion of nitriles by Candida guilliermondii CCT 7207 cells immobilized in barium alginate. Appl Microbiol Biotechnol 2001, 56:757-761.

128. Liu ZQ, Zhou M, Zhang XH, Xu JM, Xue YP, Zheng YG: Biosynthesis of iminodiacetic acid from iminodiacetonitrile by immobilized recombinant Escherichia coli harboring nitrilase. J Mol Microbiol Biotechnol 2012, 22:35-47.

129. Kumar S, Mohan U, Kamble AL, Pawar S, Banerjee UC: Cross-linked enzyme aggregates of recombinant Pseudomonas putida nitrilase for 
enantioselective nitrile hydrolysis. Bioresource Technol 2010, 101:6856-6858.

130. Bartling D, Seedorf M, MithÖFer A, Weiler EW: Cloning and expression of an Arabidopsis nitrilase which can convert indole-3-acetonitrile to the plant hormone, indole-3-acetic acid. Eur J Biochem 1992, 205:417-424.

131. Pekarsky Y, Campiglio M, Siprashvili Z, Druck T, Sedkov Y, Tillib S, Draganescu A, Wermuth P, Rothman JH, Huebner K, Buchberg AM, Mazo A, Brenner C, Croce CM: Nitrilase and Fhit homologs are encoded as fusion proteins in Drosophila melanogaster and Caenorhabditis elegans. Proc Natl Acad Sci USA 1998, 95:8744-8749.

132. Kobayashi M, Izui H, Nagasawa T, Yamada H: Nitrilase in biosynthesis of the plant hormone indole-3-acetic acid from indole-3-acetonitrile: cloning of the Alcaligenes gene and site-directed mutagenesis of cysteine residues. Proc Natl Acad Sci USA 1993, 90:247-251.

133. Kobayashi M, Yanaka N, Nagasawa T, Yamada H: Primary structure of an aliphatic nitrile-degrading enzyme, aliphatic nitrilase, from Rhodococcus rhodochrous $\mathrm{K} 22$ and expression of its gene and identification of its active site residue. Biochemistry 1992, 31:9000-9007.

134. Wu S, Fogiel AJ, Petrillo KL, Jackson RE, Parker KN, DiCosimo R, Ben-Bassat A, O'Keefe DP, Payne MS: Protein engineering of nitrilase for chemoenzymatic production of glycolic acid. Biotechnol Bioeng 2008 99:717-720.

135. Zhu D, Mukherjee C, Yang Y, Rios BE, Gallagher DT, Smith NN, Biehl ER, Hua L: A new nitrilase from Bradyrhizobium japonicum USDA 110: Gene cloning, biochemical characterization and substrate specificity. J Biotechnol 2008, 133:327-333.

136. Kaplan O, Bezouška K, Malandra A, Veselá A, Petř́ǐcková A, Felsberg J, Rinágelová A, Křen V, Martínková L: Genome mining for the discovery of new nitrilases in filamentous fungi. Biotechnol Lett 2011, 33:309-312.

137. Schreiner U, Hecher B, Obrowsky S, Waich K, Klempier N, Steinkellner G, Gruber K, Rozzell JD, Glieder A, Winkler M: Directed evolution of Alcaligenes faecalis nitrilase. Enzyme Microb Technol 2010, 47:140-146.

138. Yeom S-J, Kim H-J, Lee J-K, Kim D-E, Oh D-K: An amino acid at position 142 in nitrilase from Rhodococcus rhodochrous ATCC 33278 determines the substrate specificity for aliphatic and aromatic nitriles. Biochem J 2008, 415:401-407.

139. Kiziak C, Stolz A: Identification of amino acid residues responsible for the enantioselectivity and amide formation capacity of the arylacetonitrilase from Pseudomonas fluorescens EBC191. Appl Environ Microbiol 2009, 75:5592-5599.

140. Sosedov O, Baum S, Burger S, Matzer K, Kiziak C, Stolz A: Construction and application of variants of the Pseudomonas fluorescens EBC191 arylacetonitrilase for increased production of acids or amides. Appl Environ Microbiol 2010, 76:3668-3674.

141. Petříčková A, Sosedov O, Baum S, Stolz A, Martínková L: Influence of point mutations near the active site on the catalytic properties of fungal arylacetonitrilases from Aspergillus niger and Neurospora crassa. J Mol Catal B: Enzym 2012, 77:74-80.

142. Chuck R: A catalytic green process for the production of niacin. Chimia 2001, 54:508-513.

143. Sharma NN, Sharma M, Kumar H, Bhalla TC: Nocardia globerula NHB-2: Bench scale production of nicotinic acid. Process Biochem 2006, 41:2078-2081.

144. Chuck R: Green sustainable chemistry in the production of nicotinates. In Sustainable Industrial Chemistry. Edited by Cavani F, Centi G, Perathoner S, Trifiró F. Weinheim: Wiley-VCH Verlag GmbH \& Co. KGaA; 2009:541-550.

145. DeSantis G, Zhu Z, Greenberg WA, Wong K, Chaplin J, Hanson SR, Farwell B, Nicholson LW, Rand CL, Weiner DP, Robertson DE, Burk MJ: An enzyme library approach to biocatalysis: development of nitrilases for enantioselective production of carboxylic acid derivatives. J Am Chem Soc 2002, 124:9024-9025.

146. Gröger H: Enzymatic routes to enantiomerically pure aromatic a-hydroxy carboxylic acids: a further example for the diversity of biocatalysis. Adv Synth Catal 2001, 343:547-558.

147. Zhang Z-J, Pan J, Liu J-F, Xu J-H, He Y-C, Liu Y-Y: Significant enhancement of $(R)$-mandelic acid production by relieving substrate inhibition of recombinant nitrilase in toluene-water biphasic system. J Biotechnol 2011, 152:24-29.

148. Xiao M, Huang Y, Meng C, Guo Y: Kinetics of asymmetric reduction of phenylglyoxylic acid to $R$-(-)-mandelic acid by Saccharomyces Cerevisiae FD11b. Chin J Chem Eng 2006, 14:73-80.
149. Straathof AJJ, Sie S, Franco TT, van der Wielen LAM: Feasibility of acrylic acid production by fermentation. Appl Microbiol Biotechnol 2005, 67:727-734

150. Xu X, Lin J, Cen P: Advances in the research and development of acrylic acid production from biomass. Chin J Chem Eng 2006, 14:419-427.

151. Zabaznaya E, Kozulin S, Voronin S: Selection of strains transforming acrylonitrile and acrylamide into acrylic acid. Appl Biochem Microbiol 1998, 34:341-345.

152. Nagasawa T, Nakamura T, Yamada H: Production of acrylic acid and methacrylic acid using Rhodococcus rhodochrous $\mathrm{J1}$ nitrilase. Appl Microbiol Biotechnol 1990, 34:322-324.

153. Luo H, Wang T, Yu H, Yang H, Shen Z: Expression and catalyzing process of the nitrilase in Rhodococcus rhodochrous tg1-A6. Mod Chem Ind 2006, 26:109-111.

154. Shi Y, Sun H, Lu D, Le Q, Chen D, Zhou Y: Separation of glycolic acid from glycolonitrile hydrolysate by reactive extraction with tri-n-octylamine. Sep Purif Technol 2006, 49:20-26.

155. Panova A, Mersinger LJ, Liu Q, Foo T, Roe DC, Spillan WL, Sigmund AE, Ben-Bassat A, Wagner LW, O'Keefe DP, Wu S, Petrillo KL, Payne MS, Breske ST, Gallagher FG, DiCosimo R: Chemoenzymatic synthesis of glycolic acid. Adv Synth Catal 2007, 349:1462-1474.

156. Zhou XF, Zhang YL, Xu DQ, Cao WH, Dai CM, Qiang ZM, Yang Z, Zhao JF: Treatment of succinonitrile wastewater by immobilized high efficiency microorganism strains. Water Sci Technol 2008, 58:911-918.

157. McBride KE, Kenny JW, Stalker DM: Metabolism of the herbicide bromoxynil by Klebsiella pneumoniae subsp. ozaenae. Appl Environ Microbiol 1986, 52:325-330.

158. Sewell BT, Berman MN, Meyers PR, Jandhyala D, Benedik MJ: The cyanide degrading nitrilase from Pseudomonas stutzeri AK61 is a two-fold symmetric, 14-subunit spiral. Structure 2003, 11:1413-1422.

159. Fischer-Colbrie G, Matama T, Heumann S, Martinkovac L, Paulob AC, Guebitz $\mathrm{G}$ : Surface hydrolysis of polyacrylonitrile with nitrile hydrolysing enzymes from Micrococcus luteus BST20. J Biotechnol 2007, 129:62-68.

160. Tauber MM, Cavaco-Paulo A, Robra K-H, Gubitz GM: Nitrile hydratase and amidase from Rhodococcus rhodochrous hydrolyze acrylic fibers and granular polyacrylonitriles. Appl Environ Microbiol 2000, 66:1634-1638.

161. Battistel E, Morra M, Marinetti M: Enzymatic surface modification of acrylonitrile fibers. App/ Surf Sci 2001, 177:32-41.

162. Matamá T, Carneiro F, Caparrós C, Gübitz GM, Cavaco-Paulo A: Using a nitrilase for the surface modification of acrylic fibres. Biotechnol J 2007, 2:353-360.

163. Feng L-L, Zhang J-F, Luo H, Li Z: Surface modification of acrylonitrile fibers and membrane by nitrilase from Escherichia coli BL21 (DE3)/pET-Nit. Adv Mater Res 2011, 175-176:651-655.

164. Burton SG, Cowan DA, Woodley JM: The search for the ideal biocatalyst. Nat Biotechnol 2002, 20:37-45.

165. Martínková L, Křen V: Biotransformations with nitrilases. Curr Opin Chem Biol 2010, 14:130-137.

166. Gavagan JE, DiCosimo R, Eisenberg A, Fager SK, Folsom PW, Hann EC, Schneider KJ, Fallon RD: A Gram-negative bacterium producing a heat-stable nitrilase highly active on aliphatic dinitriles. Appl Microbio/ Biotechnol 1999, 52:654-659.

\section{doi:10.1186/1475-2859-11-142}

Cite this article as: Gong et al:: Nitrilases in nitrile biocatalysis: recent progress and forthcoming research. Microbial Cell Factories 2012 11:142. 